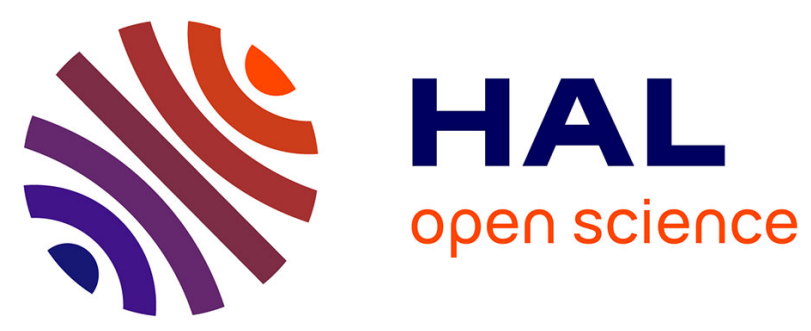

\title{
Reworked restite enclave: Petrographic and mineralogical constraints from the Tongshanling intrusion, Nanling Range, South China
}

Xu-Dong Huang, Jian-Jun Lu, Stanislas Sizaret, Ru-Cheng Wang, Jin-Wei Wu, Dong-Sheng Ma

\section{To cite this version:}

Xu-Dong Huang, Jian-Jun Lu, Stanislas Sizaret, Ru-Cheng Wang, Jin-Wei Wu, et al.. Reworked restite enclave: Petrographic and mineralogical constraints from the Tongshanling intrusion, Nanling Range, South China. Journal of Asian Earth Sciences, 2018, 166, pp.1-18. 10.1016/j.jseaes.2018.07.001 . insu-01856863

\section{HAL Id: insu-01856863 \\ https://hal-insu.archives-ouvertes.fr/insu-01856863}

Submitted on 10 Dec 2019

HAL is a multi-disciplinary open access archive for the deposit and dissemination of scientific research documents, whether they are published or not. The documents may come from teaching and research institutions in France or abroad, or from public or private research centers.
L'archive ouverte pluridisciplinaire HAL, est destinée au dépôt et à la diffusion de documents scientifiques de niveau recherche, publiés ou non, émanant des établissements d'enseignement et de recherche français ou étrangers, des laboratoires publics ou privés. 


\title{
Reworked restite enclave: Petrographic and mineralogical constraints from the Tongshanling intrusion, Nanling Range, South China
}

\author{
Xu-DongHuang ${ }^{\text {ab }}$ Jian-JunLu $^{\mathrm{a}}$ StanislasSizaret $^{\mathrm{b}}$ Ru-ChengWang ${ }^{\mathrm{a}}$ Jin-WeiWu $^{\mathrm{a}}$ Dong-ShengMa ${ }^{\mathrm{a}}$ \\ A : State Key Laboratory for Mineral Deposits Research, School of Earth Sciences and \\ Engineering, Nanjing University, Nanjing 210023, China \\ B : Institut des Sciences de la Terre d'Orléans, UMR 7327-CNRS/Université \\ d'Orléans/BRGM, Orléans 45071, France
}

\begin{abstract}
Microgranular enclaves, which can provide important petrogenetic indications for the host granitoids, are commonly observed in the Middle-Late Jurassic $\mathrm{Cu}-\mathrm{Pb}-\mathrm{Zn}$-bearing granodiorites in the Nanling Range of South China. The origin of these $\mathrm{Cu}-\mathrm{Pb}-\mathrm{Zn}$-bearing granodiorites is still controversial, with two different hypotheses: crust-mantle mixing and partial melting of the mafic lower crust, primarily based on geochemistry and geochronology. Detailed petrographic and mineralogical studies have been carried out on the Tongshanling granodiorite and its microgranular enclaves to provide new textural and compositional constraints on the petrogenesis. The microgranular enclaves have dioritic compositions with a mineralogy dominated by plagioclase, amphibole, and biotite. Abundant residual materials, such as mafic mineral clots, inherited and metamorphic zircon, and Ca-rich core plagioclase, occur in the enclaves and are in favor of a restite origin. The amphibole-rich clots are considered as vestiges of residual pyroxene-rich precursors from the source. Three different types of amphibole, i.e., magmatic, metamorphic, and magma reworked metamorphic amphibole, have been recognized in the granodiorite and its enclaves. The magmatic amphibole occurs as enclosed and idiomorphic isolated crystals in the granodiorite with $\mathrm{Al}$ and $\mathrm{Si}$ contents of 1.34-2.12 apfu (atoms per formula unit) and 6.25-6.88 apfu, respectively, and a $\Sigma$ REE content of 307-764 ppm. The metamorphic amphibole, with a granoblastic triplejunction texture, occurs as aggregated crystals dominantly in the enclaves and a few in the granodiorite. It has actinolitic compositions (Al: 0.31-0.81 apfu, Si: 7.33-7.72 apfu) and distinctly lower contents of incompatible elements ( $\mathrm{REE}$ : 99-146 ppm). The magma reworked amphibole has intermediate compositions (Al: 0.81-1.59 apfu, Si: 6.71-7.35 apfu, ¿REE: $317-549 \mathrm{ppm}$ ) between the magmatic and metamorphic amphibole. The zonal amphibole-rich clots exhibit increasing $\mathrm{Al}$ and decreasing Si contents from interior amphibole to exterior amphibole and also from core to rim in amphibole grains, and the outer parts of enclave magmatic zircon have higher $\mathrm{ThO}_{2}+\mathrm{UO}_{2}$ contents and lower $\mathrm{Zr} / \mathrm{Hf}$ ratios than the inner parts, showing the process of magma reworking of the restite enclaves. Based on the textural and compositional evidence, these microgranular enclaves are thought to be reworked restite enclaves. This is also supported by thermobarometric calculation. A model illustrating the formation process of reworked restite enclave has been proposed. Combined with previous experimental studies of partial melting, the Tongshanling granodiorite is deduced to be derived from dehydration melting of amphibolite in the mafic lower crust. The fertile amphibolitic source is beneficial to the formation of $\mathrm{Cu}-\mathrm{Pb}-\mathrm{Zn}$-bearing granodiorites in the Nanling Range.
\end{abstract}


Keywords : Amphibole, Textural feature, Mineral composition, Microgranular enclave, $\mathrm{Cu}-\mathrm{Pb}-\mathrm{Zn}$-bearing granodiorite, Nanling range

\section{Introduction}

Microgranular enclaves in granitoids have long been studied, as they can provide significant information for the petrogenetic mechanism of their host granitoids. Various models have been proposed to explain the origin of microgranular enclaves, including magma mixing, restite after partial melting, accidental xenolith, and disrupted cumulate (autolith) (Didier, 1973, Didier and Barbarin, 1991), among which magma mixing (Vernon, 1984, Dorais et al., 1990, Poli and Tommasini, 1991, Blundy and Sparks, 1992, Yang et al., 2004, Yang et al., 2007, Barbarin, 2005, Zhao et al., 2010, Cheng et al., 2012, Perugini and Poli, 2012, Fu et al., 2016, Zhang et al., 2016) and restite (White and Chappell, 1977, Chappell et al., 1987, Chen et al., 1989, Chen et al., 1990, Chen et al., 1991, Chappell and White, 1991, Chappell, 1996, White et al., 1999, Chappell and Wyborn, 2012) were the most hotly debated hypotheses. In recent years, mixing of mafic and felsic magmas was the most popular petrogenetic interpretation for dark microgranular enclaves and their host granitoids which show juvenile and evolved isotopic signatures, respectively (e.g., Yang et al., 2004, Yang et al., 2007, Zhao et al., 2010, Cheng et al., 2012, Fu et al., 2016). This interpretation was also frequently cited for those granitoids and enclaves with similar isotopic compositions (e.g., Jiang et al., 2009, Liu et al., 2013, Luo et al., 2015). However, it is noteworthy that magma mixing is primarily controlled by the viscosities of different end-members, and a low viscosity interval between mafic and felsic magmas favors their mixing (Sato and Sato, 2009, Perugini and Poli, 2012, Laumonier et al., 2014a, Laumonier et al., 2014b, Laumonier et al., 2015). Under experimental conditions of $300 \mathrm{MPa}$ and relatively slow strain rates $\left(10^{-5}-10^{-3} \mathrm{~s}^{-1}\right)$, the rheological threshold for mixing of basaltic and haplotonalitic magmas under water-absent and water-saturated conditions occurs at $1160-1170{ }^{\circ} \mathrm{C}$ (Laumonier et al., 2014a) and around $1000{ }^{\circ} \mathrm{C}$ (Laumonier et al., 2015), respectively. It is inconceivable for most natural granitic magmas to keep such high temperatures to have a large-scale mixing with mafic magmas. Wu et al. (2007) pointed out that the existence of magmatic enclaves is indicative of a limited magma mixing.

In the Nanling Range of South China, dark microgranular enclaves are commonly observed in the Middle-Late Jurassic Cu-Pb-Zn-bearing granodiorites, such as the Tongshanling (Jiang et al., 2009) and Baoshan (Xie et al., 2013) granodiorites. Previous studies interpreted these enclaves as a result of mantle-derived mafic magma and crust-derived felsic magma mixing (Jiang et al., 2009, Xie et al., 2013), and it was widely considered that the Middle-Late Jurassic $\mathrm{Cu}-\mathrm{Pb}-\mathrm{Zn}$-bearing granodiorites have an origin of crust-mantle mixing (e.g., Wang et al., 2003a, Jiang et al., 2009, Li et al., 2012, Xie et al., 2013, Zhao et al., 2016). However, another hypothesis, partial melting of the mafic lower crust, has been proposed in recent years (Yang et al., 2016, X.D. Huang et al., 2017), and gave rise to a reconsideration of the origin of the $\mathrm{Cu}-\mathrm{Pb}-\mathrm{Zn}$-bearing granodiorites. The arguments for these two different interpretations were both primarily based on geochemistry and geochronology, but petrographic and mineralogical evidence was absent.

The Tongshanling intrusion, which is a typical $\mathrm{Cu}-\mathrm{Pb}-\mathrm{Zn}$-bearing granodiorite containing microgranular enclaves and has been intensely studied in terms of geochronology and geochemistry, was chosen as the research target. In this study, detailed petrographic and mineralogical researches have been carried out on the Tongshanling granodiorite and its microgranular enclaves to better constrain the genesis of microgranular enclaves and provide 
petrogenetic implications for the Middle-Late Jurassic $\mathrm{Cu}-\mathrm{Pb}-\mathrm{Zn}$-bearing granodiorites in the Nanling Range.

\section{Geological setting}

The Yangtze and Cathaysia Blocks construct the South China Craton (Fig. 1) by a Neoproterozoic amalgamation. South China is a world famous large granitic province, especially characterized by the widespread Late Mesozoic granites, which have a total exposure area of $114,400 \mathrm{~km}^{2}$ (Sun, 2006). Economically significant rare, precious, and base metal mineralization is genetically associated with these Late Mesozoic granites. PalaeoPacific plate subduction models have been proposed (Zhou and Li, 2000, Li and Li, 2007, Zhao et al., 2017) and widely applied to interpret the geodynamic mechanism of the Late Mesozoic granitic magmatism and related polymetallic mineralization in South China (e.g., Jiang et al., 2009, Liu et al., 2013, Yang et al., 2016, Zhao et al., 2016, X.D. Huang et al., 2017, Zhao and Zhou, 2018). Previous studies suggested that, under an extensional tectonic background which was induced by the palaeo-Pacific plate subduction, crust-mantle interaction played an important role in petrogenetic and metallogenic process (Zhou and Li, 2000), particularly for the Late Mesozoic Cu-polymetallic deposits (e.g., Wang et al., 2011, Li et al., 2012, Zhou et al., 2013, Zhao et al., 2016, Hu et al., 2017).

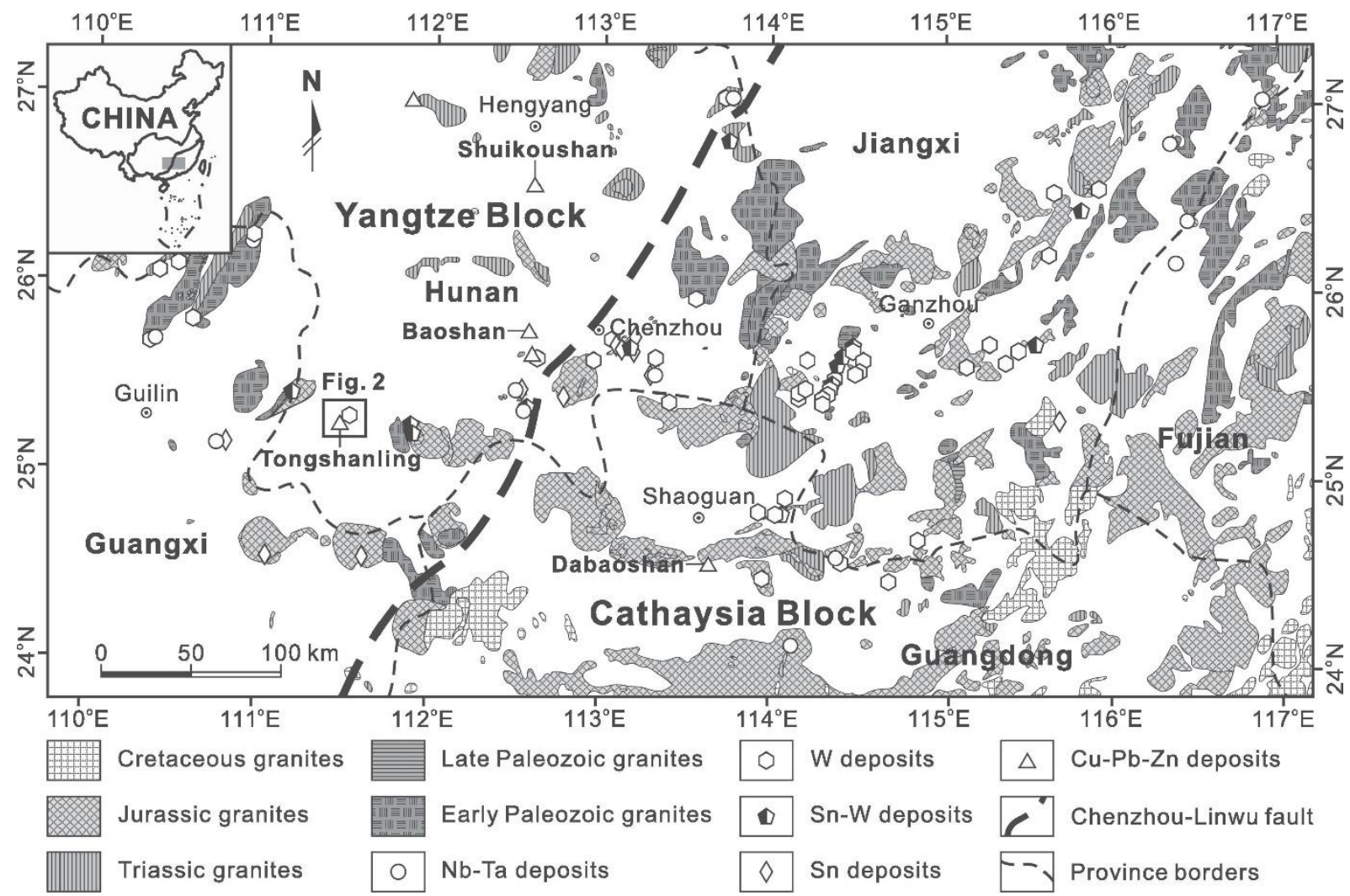

Fig. 1. Distribution of multiple-aged granites and related mineral deposits in the Nanling Range of South China (modified after Chen et al., 2008, Chen et al., 2013). 
The Nanling Range of South China is the most important W, Sn, and rare metals ore district in China. In spite of the distribution of multiple-aged granites and related deposits (Fig. 1), Middle-Late Jurassic is the most important magmatic and metallogenic epoch in the Nanling Range. The Middle-Late Jurassic ore-bearing granites in the Nanling Range can be divided into W-, Sn-, Nb-Ta-, and Cu-Pb-Zn-bearing granites (Fig. 1; Chen et al., 2008, Chen et al., 2013, X.D. Huang et al., 2017). The $\mathrm{Cu}-\mathrm{Pb}-\mathrm{Zn}$-bearing granites are mainly metaluminous, high-K calc-alkaline and weakly evolved granodiorites, which show features of I-type granites, such as the Shuikoushan, Baoshan, Tongshanling, and Dabaoshan granodiorites (Fig. 1; Wang et al., 2003a, Wang, 2010, Xie et al., 2013, Yang et al., 2016, X.D. Huang et al., 2017).

The Tongshanling area is located in the western Nanling Range and in southern Hunan Province (Fig. 1). Devonian and Carboniferous carbonate rocks constitute the predominant stratigraphy of this area (Fig. 2). The regional structures are dominated by north-south- to northeast-southwest-striking folds and faults (Fig. 2). As the main intrusive rocks in this area, the Tongshanling granodiorite and Weijia granite are genetically associated with $\mathrm{Cu}-\mathrm{Pb}-\mathrm{Zn}$ and W mineralization, respectively (Fig. 2; X.D. Huang et al., 2017).

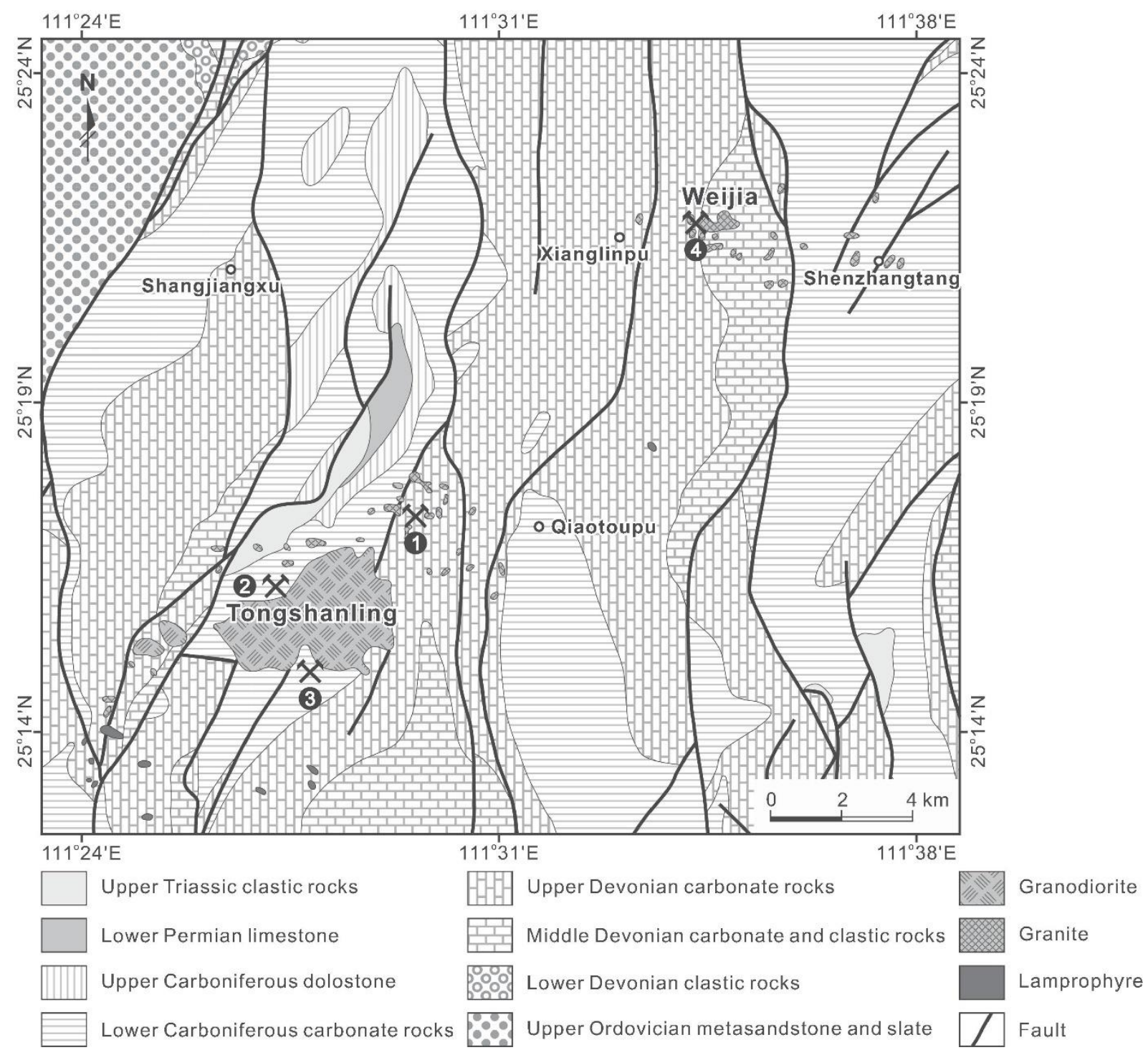


Fig. 2. Geological map of the Tongshanling area in southern Hunan Province (modified after Regional Geological Survey Team of Hunan Geology Bureau, 1975a, Regional Geological Survey Team of Hunan Geology Bureau, 1975b). 1: Tongshanling Cu-Pb-Zn deposit; 2: Jiangyong Pb-Zn-Ag deposit; 3: Yulong Mo deposit; 4: Weijia W deposit.

\section{Tongshanling granodiorite and its microgranular enclaves}

The Tongshanling intrusion as stock with a total exposure area of $12 \mathrm{~km}^{2}$ (Fig. 2) has an approximately homogeneous composition of amphibole-bearing biotite granodiorite (Fig. 3a) and does not show obvious lithological zonation except for local variation of mineral granularity. It has $\mathrm{SiO}_{2}$ contents of $63.7-70.1 \mathrm{wt} \%$ and is metaluminous (aluminum saturation index: 0.9-1.0), high- $\mathrm{K}$ calc-alkaline and weakly fractionated $\left[\mathrm{CaO} /\left(\mathrm{Na}_{2} \mathrm{O}+\mathrm{K}_{2} \mathrm{O}\right)\right.$ : 0.3-0.6; $\mathrm{Rb} / \mathrm{Sr}$ : 0.5-1.3], and shows characteristics of I-type granites (X.D. Huang et al., 2017). Three deposits, the Tongshanling $\mathrm{Cu}-\mathrm{Pb}-\mathrm{Zn}$ deposit, Jiangyong $\mathrm{Pb}-\mathrm{Zn}-\mathrm{Ag}$ deposit, and Yulong $\mathrm{Mo}$ deposit, are distributed around this intrusion (Fig. 2). These deposits occur in the concealed contact zone between granodiorite and carbonate rocks, and its peripheral zone. By zircon U$\mathrm{Pb}$ and molybdenite $\mathrm{Re}-\mathrm{Os}$ dating, it was revealed that the Tongshanling granodiorite (164160 Ma; Jiang et al., 2009, Zhao et al., 2016, X.D. Huang et al., 2017) and its surrounding deposits (162-160 Ma; Huang and Lu, 2014, Lu et al., 2015, Zhao et al., 2016) were formed contemporaneously. 

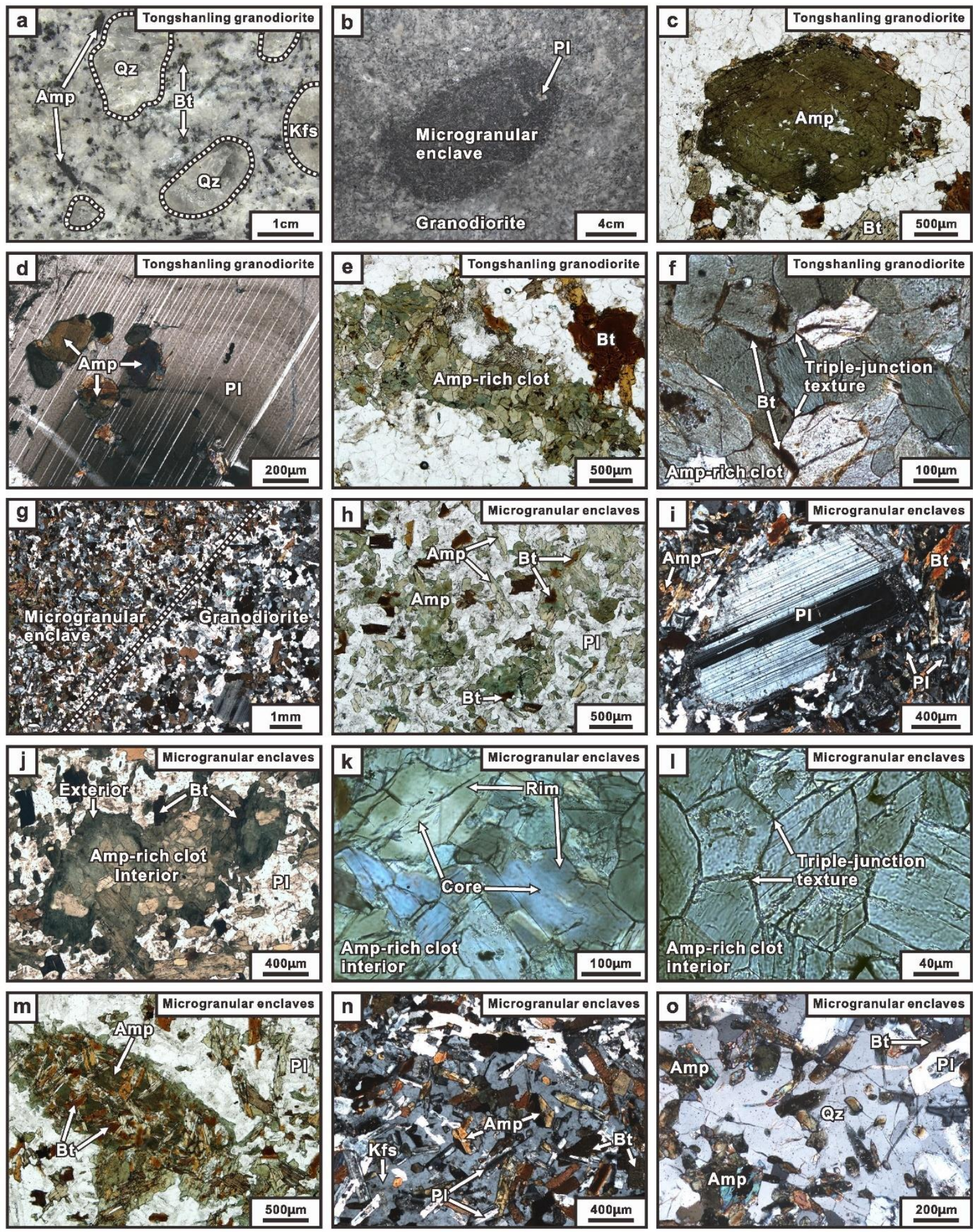

Fig. 3. Petrographic photographs of the Tongshanling granodiorite and its microgranular enclaves. (a) Medium- to coarse-grained and porphyritic texture of the amphibole-bearing biotite granodiorite at specimen scale. (b) An ellipsoidal dark enclave in the granodiorite, which contains a few plagioclase phenocrysts, shows a gradational contact with the host, and does not have a chilled margin with magmatic flow foliation. (c) Idiomorphic and isolated amphibole in the granodiorite, plane-polarized light. (d) Enclosed amphibole in the granodiorite, crossed-polarized light. (e) Amphibole-rich clot in the granodiorite, which is 
mainly comprised of aggregated fine-grained amphibole with a few biotite and plagioclase, plane-polarized light. (f) Granoblastic triple-junction texture of the amphibole-rich clot with a few interstitial anhedral biotite crystals, in the granodiorite, plane-polarized light. (g) Gradational transition from an enclave to the host granodiorite with increasing mineral granularity and decreasing proportion of mafic minerals, crossed-polarized light. (h) The enclaves are mainly composed of plagioclase, amphibole, and biotite, the mafic minerals are anhedral to subhedral and are dominated by amphibole with a few biotite, the amphibole occurs dominantly as aggregated with fewer isolated crystals, plane-polarized light. (i) Reaction rim of a plagioclase phenocryst which does not have a Ca-rich core, in the enclaves, crossed-polarized light. (j) Amphibole-rich clot in the enclaves, which has a pale-green to colorless interior and a green colored exterior, plane-polarized light. (k) Zonal amphibole crystals in the amphibole-rich clot interior with paler colored cores and deeper colored rims, in the enclaves, plane-polarized light. (1) Granoblastic triple-junction texture of the amphibole-rich clot interior without interstitial biotite, in the enclaves, plane-polarized light. (m) Intergrowth of biotite and amphibole in an amphibole-biotite clot which does not show zonal feature and granoblastic triple-junction texture, in the enclaves, plane-polarized light. (n) Poikilitic texture of a large-grained K-feldspar crystal in the enclaves, crossed-polarized light. (o) Poikilitic texture of a large-grained quartz crystal in the enclaves, crossed-polarized light. $\mathrm{Amp}=$ amphibole, $\mathrm{Bt}=$ biotite, $\mathrm{Kfs}=\mathrm{K}$-feldspar, $\mathrm{Pl}=$ plagioclase, $\mathrm{Qz}=$ quartz.

Dark microgranular enclaves are commonly found scattered throughout the Tongshanling granodiorite. They occur as separate individuals, which are several to dozens of centimeters in size and generally have round to ellipsoid shapes (Fig. 3b). The contact of the enclaves with the host rock is gradational (Fig. 3b), and chilled margin and magmatic flow foliation are absent. Most enclaves are fine-grained and homogeneous, and some contain a few plagioclase phenocrysts (Fig. 3b). Previous zircon U-Pb geochronology showed that they were formed at 163-160 Ma (Jiang et al., 2009, X.D. Huang et al., 2017), which is identical to that of the host granodiorite. These enclaves mostly have dioritic compositions (53.4-59.4 wt\% $\mathrm{SiO}_{2}$ ), and show similar $\mathrm{Mg} /(\mathrm{Mg}+\mathrm{Fe})$ ratios (0.4-0.5) and HREE-depleted REE patterns with the host rock, but higher $\Sigma$ REE contents and larger negative Eu anomalies (X.D. Huang et al., 2017).

\section{Petrography}

\subsection{Tongshanling granodiorite}

The Tongshanling granodiorite is medium- to coarse-grained, porphyritic (Fig. 3a), and consists primarily of plagioclase (ca. 45 vol\%), K-feldspar (ca. 22 vol\%), quartz (ca. $20 \mathrm{vol} \%$ ), biotite (ca. $10 \mathrm{vol} \%$ ), and amphibole (ca. 3 vol\%). The phenocrysts are mainly $1-$ $5 \mathrm{~cm}$ sized, except for some local plagioclase megacrysts with a size up to $10 \mathrm{~cm}$. Plagioclase is primarily euhedral to subhedral oligoclase to andesine with zonal texture, and occasionally includes a sericitized core which has an embayed margin and generally occupies less than $30 \mathrm{vol} \%$ of the whole plagioclase (Fig. 4a). Amphibole is green colored and mostly occurs as euhedral (Fig. 3c) to subhedral isolated crystals, and occasionally as mineral inclusions (i.e., enclosed amphibole) in plagioclase (Fig. 3d) and K-feldspar. Besides the isolated and enclosed amphibole, another rare but remarkable amphibole is aggregated crystals which constitute millimetric polycrystalline amphibole-rich clots together with a few biotite and plagioclase (Fig. 3e). The aggregated amphibole is obviously finer grained $(<300 \mu \mathrm{m})$ than the isolated ones and is generally connected by a granoblastic triple-junction texture (Fig. $3 \mathrm{f}$ ). 
Biotite is brown and dominantly distributes in the matrix as euhedral to subhedral crystals. A few anhedral biotite crystals are distributed as interstitial along the boundary between the aggregated amphibole grains (Fig. 3f). Accessory minerals include zircon, apatite, titanite, allanite, rutile, sulfide, and Fe-Ti oxide minerals. The Fe-Ti oxide minerals are dominated by magnetite.
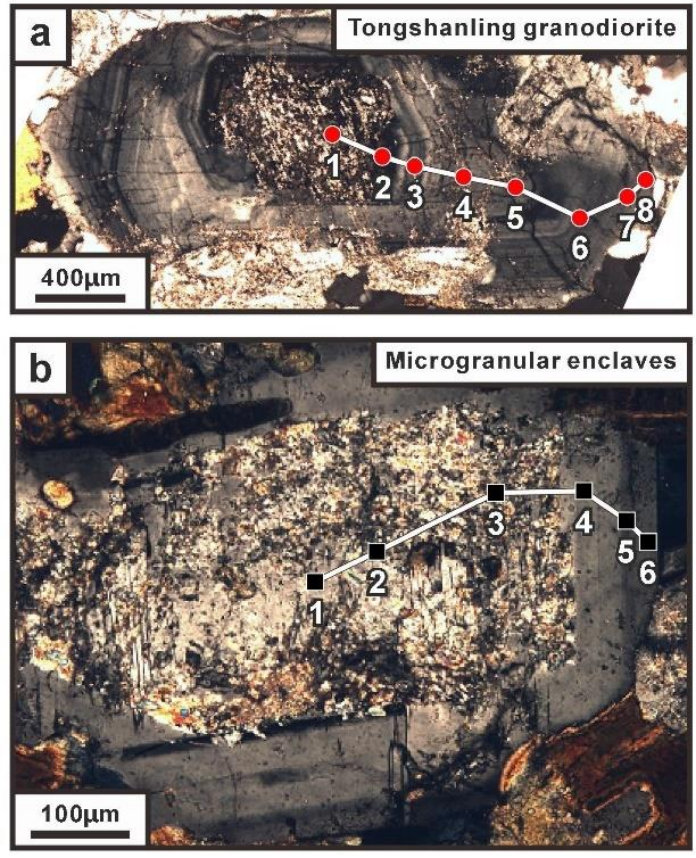
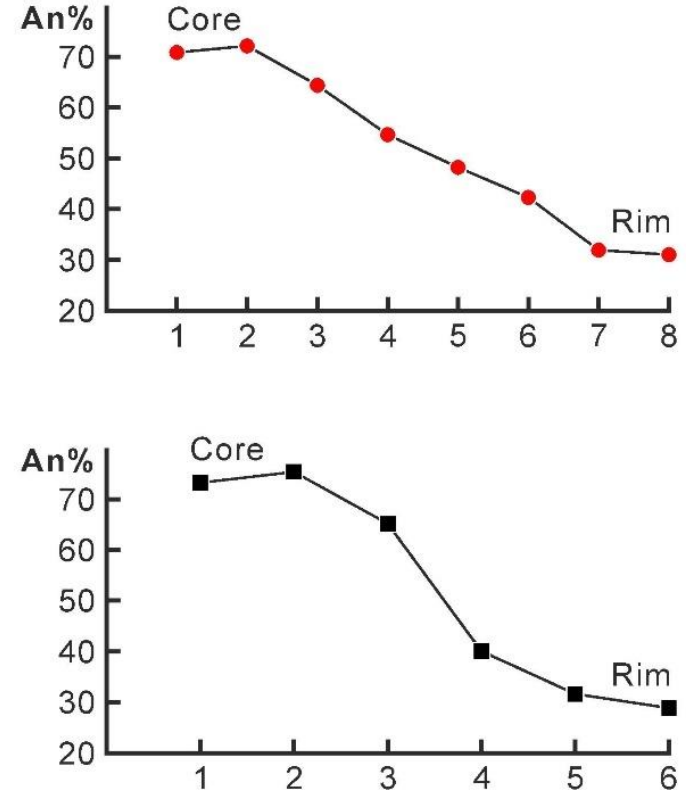

Fig. 4. Compositional zonation of plagioclase with a Ca-rich core (analysis was performed on the unaltered part) from the Tongshanling granodiorite and its microgranular enclaves.

\subsection{Microgranular enclaves}

The fine-grained (Fig. 3g) dioritic dark enclaves have the same minerals, even accessory minerals, as their host granodiorite but in different proportions. They generally have a plagioclase content of 50-60 vol\%, and 30-50 vol\% of mafic minerals (Fig. 3g and h), with a few K-feldspar and quartz. The mafic minerals of most enclaves are dominated by amphibole (Fig. 3h), with the exception of some dominated by biotite. At the contact between the enclaves and their host rock, the mineral granularity and proportion of mafic minerals change gradually rather than sharply (Fig. 3g). Plagioclase is mainly subhedral to anhedral and sometimes euhedral crystals which mostly consist of a sericitized core with an irregular margin and a fresh rim with zonal texture (Fig. 4b). The sericitized core accounts for at least $60 \mathrm{vol} \%$ of the whole plagioclase (Fig. 4b). Notably, the quantity of core-bearing plagioclase and the proportion of sericitized core in the enclaves are much more than those in the host granodiorite. The plagioclase phenocrysts with a reaction rim and no sericitized cores (Fig. 3i) appear occasionally. Biotite is brown and occurs primarily as anhedral to subhedral crystals. Compared with the host granodiorite, the majority of amphibole in the enclaves occurs as aggregated rather than isolated crystals (Fig. 3h). The ratio of the aggregated and isolated amphibole contents is about 5:1. The aggregated amphibole, which mainly constitutes amphibole-rich clots together with a few biotite, is anhedral and has a similar grain size $(<300 \mu \mathrm{m})$ with the most other enclave minerals (Fig. 3h and j). The isolated amphibole is 
mostly anhedral to subhedral (Fig. 3h) and never appears as idiomorphic as that in the host granodiorite (Fig. 3c). Nearly half of the amphibole-rich clots are several millimeters sized and are zoned with a pale-green to colorless interior and a deep-green colored exterior (Fig. $3 \mathrm{j}$ ); the another half is smaller in size and does not show a color zonation (Fig. 3h). Although not always, the interior amphibole grains in the zonal clots also show a zonal feature, with the core being paler colored than the rim (Fig. 3k). However, the clot exterior amphibole grains do not show a color zonation. A granoblastic triple-junction texture can be commonly observed in the clot interior where only amphibole appears but no interstitial biotite does (Fig. 31), whereas the clot exterior shows an anhedral granular texture of dominant amphibole and a few biotite crystals (Fig. 3j). The biotite in the clot exterior occupies no more than $5 \mathrm{vol} \%$ of the clot. Besides the amphibole-rich clots, some rarely-occurred mafic mineral clots are composed of amphibole and abundant biotite with an intergrowth texture, and do not have zonal feature and granoblastic triple-junction texture (Fig. $3 \mathrm{~m}$ ). In these amphibole-biotite clots, the content of biotite is about $40-50 \mathrm{vol} \%$. A few large-grained $\mathrm{K}$-feldspar and quartz have a poikilitic texture and include the fine-grained amphibole, biotite, and plagioclase (Fig. $3 n$ and o).

\section{Analytical methods}

Major element analyses of plagioclase, amphibole, and biotite were carried out with a CAMECA SX50 electron microprobe (EMP) at Institut des Sciences de la Terre d'Orléans (ISTO), France. Zircon was analyzed by a JEOL JXA-8100 M EMP at the State Key Laboratory for Mineral Deposits Research (LAMD), Nanjing University (NJU), China. The analytical conditions included an accelerating voltage of $15 \mathrm{kV}$, a beam current of $10 \mathrm{nA}$ (CAMECA, ISTO) or 20nA (JEOL, LAMD, NJU) with beam diameter of $1 \mu \mathrm{m}$, and counting times of $10 \mathrm{~s}$ for all elements and $5 \mathrm{~s}$ for background. The collected data were corrected by the ZAF procedures. Calibration was performed using natural minerals and synthetic compounds.

Trace element contents of amphibole and biotite were determined by an Agilent $7700 \times$ inductively coupled plasma mass spectrometry coupled to an Excite $193 \mathrm{~nm}$ Photon Machines laser ablation system (LA-ICP-MS) at Nanjing FocuMS Technology Co. Ltd. Each analysis was performed by a $25-50-\mu \mathrm{m}$ ablating spot at $5-8 \mathrm{~Hz}$ with energy of $5-5.5 \mathrm{~mJ}$ (transmittance $80 \%$ ) for $40 \mathrm{~s}$ after measuring the gas blank for $15 \mathrm{~s}$. USGS standard reference materials BIR1G, BHVO-2G, and BCR-2G, NIST standard reference material 610, and Chinese Geological Standard Glasses CGSG-1 and CGSG-2 were used as external standards to plot calibration curve. GSE-1G was analyzed for quantity control of the time-dependent calibration for sensitivity drift. The off-line data processing was performed using a program called ICPMSDataCal (Liu et al., 2008).

\section{Analytical results}

\subsection{Plagioclase}

Representative microprobe analyses of plagioclase from the Tongshanling granodiorite and its microgranular enclaves are listed in Supplementary Table S1. In the granodiorite, most plagioclase crystals show an anorthite range from $\mathrm{An}_{21}$ to $\mathrm{An}_{48}$ (Fig. 5). The plagioclase with a sericitized core has an anorthite content of $A n_{71}-A_{72}$ and $A n_{31}-A n_{64}$ at the core and rim, respectively (Fig. 4a). In the enclaves, the plagioclase rims have an anorthite content of $\mathrm{An}_{22}$ - An 45 , similar to that of the core-free plagioclase in the host granodiorite, whereas, the sericitized cores show an anorthite range from $A_{65}$ to $A_{76}$ (Fig. 5). Thus, the enclave plagioclase shows a discontinuous compositional change from core to rim (Fig. 4b). The Ca- 
rich plagioclase cores of both the granodiorite and its enclaves are almost uniform in composition without obvious zonation (Fig. 4).

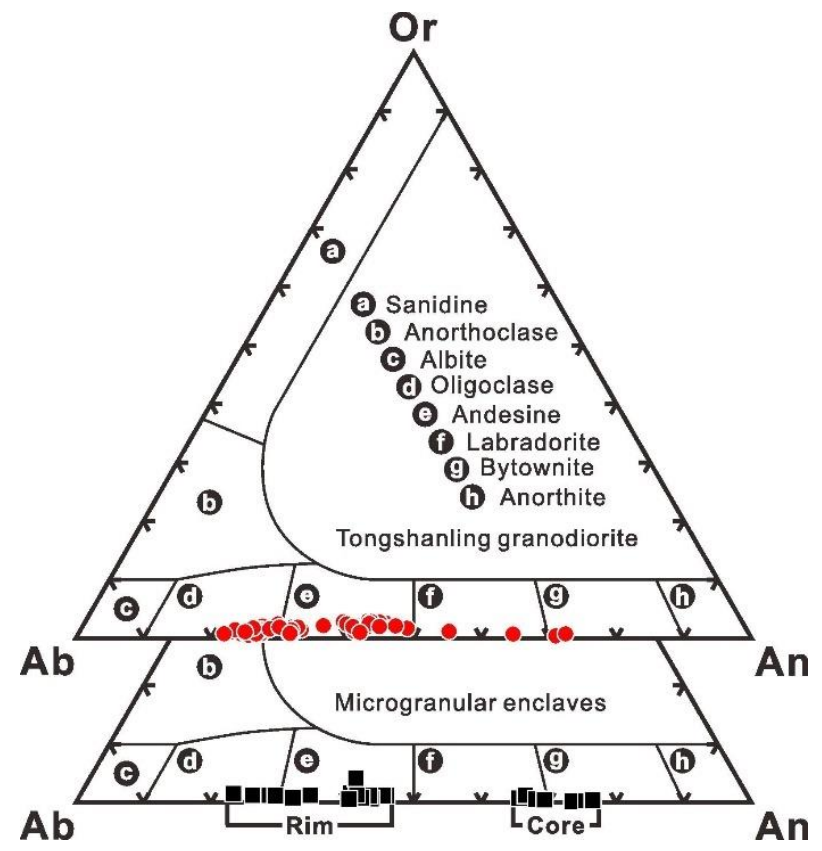

Fig. 5. Composition of plagioclase from the Tongshanling granodiorite and its microgranular enclaves.

\subsection{Amphibole}

The different occurrences of amphibole (i.e., enclosed, isolated, and aggregated) in the Tongshanling granodiorite and its enclaves are all calcium amphibole, and show a large compositional variation, but have quite consistent $\mathrm{Mg} /(\mathrm{Mg}+\mathrm{Fe})$ ratios $(0.44-0.58)$ (Fig. 6; Supplementary Table S2). In the classification of Hawthorne et al. (2012), for the granodiorite, the enclosed and most isolated crystals plot in the pargasite field; some isolated ones plot in the magnesio-hornblende field; the core and rim of aggregated amphibole grains plot in the transition field from tremolite to magnesio-hornblende and in the magnesiohornblende field, respectively (Fig. 6a). For the enclaves, the core and rim of clot interior amphibole grains plot in the tremolite and in the transition field from tremolite to magnesiohornblende, respectively; both the clot exterior amphibole and the isolated amphibole plot in the magnesio-hornblende field (Fig. 6a). 

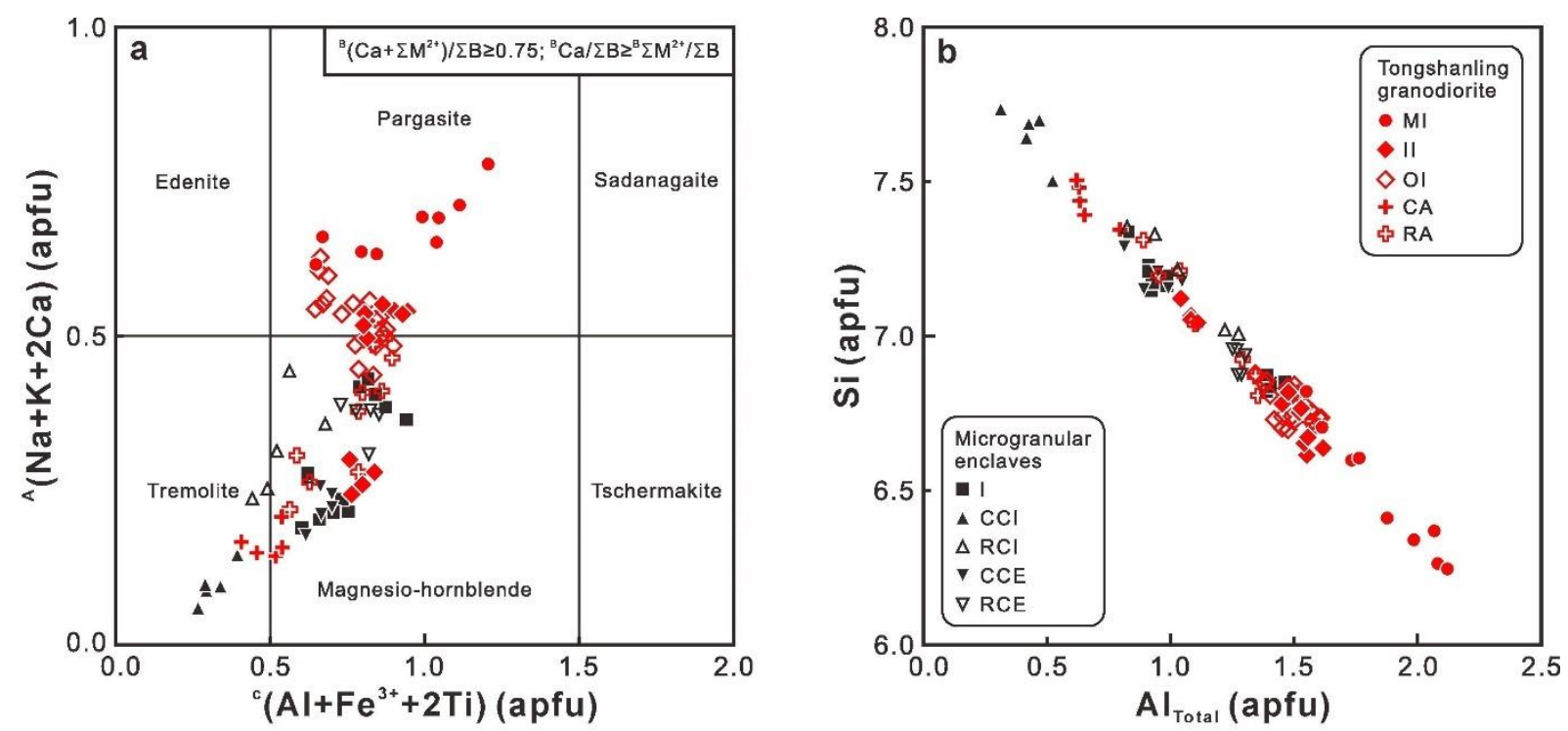

Fig. 6. Mineral chemistry of amphibole from the Tongshanling granodiorite and its microgranular enclaves. (a) Classification diagram of amphibole (General formula: $\mathrm{A}_{0-1} \mathrm{~B}_{2} \mathrm{C}_{5} \mathrm{~T}_{8} \mathrm{O}_{22}(\mathrm{OH}, \mathrm{F}, \mathrm{Cl})_{2}$, after Hawthorne et al., 2012), when $\mathrm{Mg} /\left(\mathrm{Mg}+\mathrm{Fe}^{2+}\right)<0.9$, the tremolite field represents an actinolitic composition (according to Leake et al., 1997). (b) Si (apfu)-Al Total $_{\text {(apfu) diagram. MI: mineral }}$ inclusion; II: inner of isolated amphibole; OI: outer of isolated amphibole; CA: core of aggregated amphibole grains; RA: rim of aggregated amphibole grains; I: isolated amphibole; CCI: core of clot interior amphibole grains; RCI: rim of clot interior amphibole grains; CCE: core of clot exterior amphibole grains; RCE: rim of clot exterior amphibole grains.

Among all the different occurrences of amphibole, the enclosed amphibole in the granodiorite has the highest Al [1.55-2.12 apfu (atoms per formula unit)] and lowest Si (6.25-6.82 apfu) contents (Fig. 6b). Most isolated amphibole crystals in the granodiorite have Al contents of 1.34-1.62 apfu and Si contents of 6.62-6.88 apfu and a few have obviously lower Al (1.04$1.11 \mathrm{apfu}$ ) and higher Si (7.04-7.12 apfu) contents (Fig. 6b). The aggregated amphibole of both the granodiorite and its enclaves shows distinctly lower Al and higher Si contents than the enclosed and dominant isolated amphibole in the granodiorite (Fig. 6b). The core of aggregated amphibole grains in the granodiorite has lower Al contents $(0.63-0.81 \mathrm{apfu})$ and higher Si contents (7.33-7.49 apfu) than the rim (Al: 0.90-1.59 apfu; Si: 6.71-7.31 apfu) (Fig. 6b). Particularly, the core of clot interior amphibole grains in the enclaves shows actinolitic compositions $\left[\mathrm{Mg} /\left(\mathrm{Mg}+\mathrm{Fe}^{2+}\right)<0.9\right.$; Fig. 6a; Supplementary Table S2] with the lowest $\mathrm{Al}$ (0.31-0.52 apfu) and highest Si (7.49-7.72 apfu) contents and the rim has higher Al (0.82$1.28 \mathrm{apfu}$ ) and lower Si (7.01-7.35 apfu) contents than the core (Fig. 6b). Notably, although the clot exterior amphibole grains do not show a color zonation, they have zoned compositions, with the core having lower $\mathrm{Al}$ contents (0.81-1.05 apfu) and higher Si contents (7.16-7.30 apfu) than the rim (Al: 1.25-1.30 apfu; Si: 6.88-6.97 apfu) (Fig. 6b). At clot scale, the exterior of zonal amphibole-rich clots shows more Al-enriched and Si-depleted amphibole compositions than those of the interior (Fig. 6b). The isolated amphibole in the enclaves can be divided into two different groups with low-Al, high-Si and high-Al, low-Si compositions, respectively (Fig. 6).

Trace element compositions of amphibole are listed in Supplementary Table S3. The isolated amphibole in the granodiorite has flat REE patterns with weak LREE depletions and obvious Eu negative anomalies (Fig. 7a). The $\Sigma$ REE contents are 307-764 ppm and the mean $\delta \mathrm{Eu}$ $\left[\delta \mathrm{Eu}=2 \mathrm{Eu}_{\mathrm{N}} /\left(\mathrm{Sm}_{\mathrm{N}}+\mathrm{Gd}_{\mathrm{N}}\right)\right]$ value is 0.05 . The rim of clot interior amphibole grains and the 
isolated amphibole in the enclaves, with $\Sigma$ REE contents of 485-525 ppm and 317-549 ppm, respectively, have the similar REE patterns and mean $\delta$ Eu value $(0.06)$ (Fig. $7 \mathrm{~b}$ and c) to the isolated amphibole in the granodiorite. In contrast, although the core of clot interior amphibole grains in the enclaves also shows flat REE patterns with weak LREE depletions, it has distinctly lower $\Sigma$ REE contents (99-146 ppm) and a slightly higher mean $\delta$ Eu value $(0.09)$ (Fig. 7b). In the trace element binary diagrams (Fig. 8), it is clearly separated from the other occurrences of amphibole by lower contents of $\mathrm{Rb}, \mathrm{Sr}, \mathrm{Cs}, \mathrm{Ba}, \mathrm{Zr}, \mathrm{Hf}, \mathrm{Nb}, \mathrm{Ta}, \mathrm{Th}, \mathrm{U}, \mathrm{\Sigma REE}$, $\mathrm{Y}, \mathrm{Zn}, \mathrm{Pb}, \mathrm{Sn}, \mathrm{W}, \mathrm{V}, \mathrm{Sc}, \mathrm{Ga}$, and In.

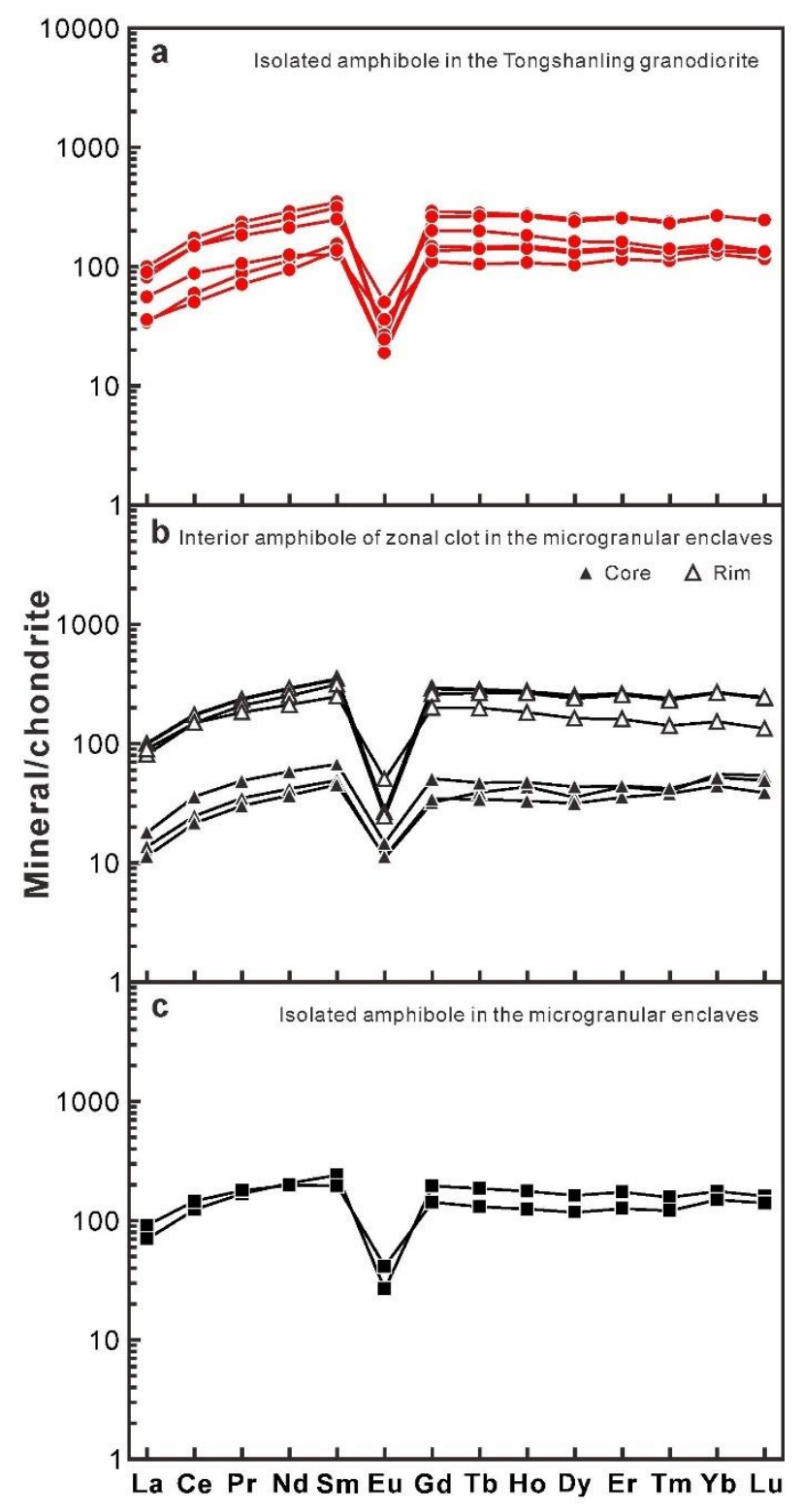

Fig. 7. Chondrite-normalized (Boynton, 1984) REE patterns of amphibole from the Tongshanling granodiorite and its microgranular enclaves. 

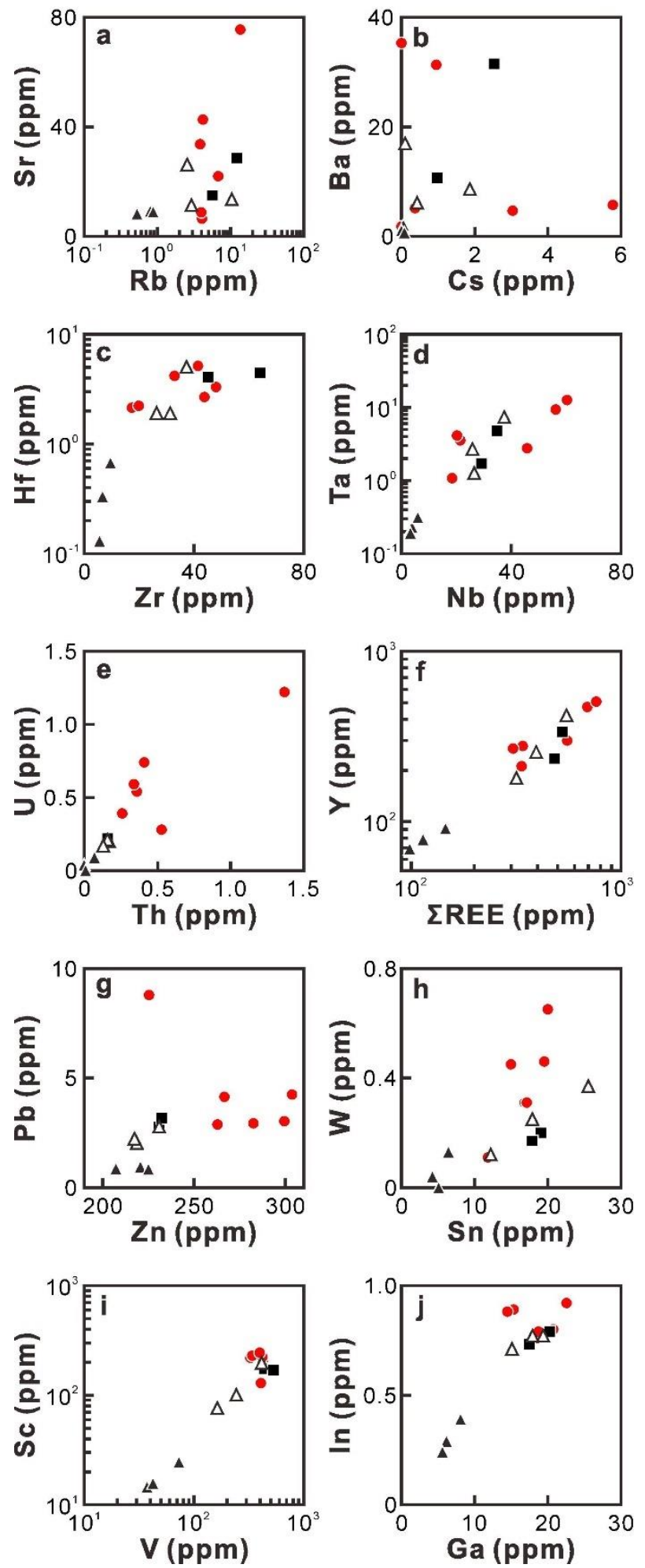

Fig. 8. Trace element binary diagrams of amphibole from the Tongshanling granodiorite and its microgranular enclaves. Legends are the same as Fig. 7.

\subsection{Biotite}

Biotite crystals of the Tongshanling granodiorite and its microgranular enclaves have similar major element compositions (Supplementary Table S4). Their $\mathrm{Mg} /(\mathrm{Mg}+\mathrm{Fe}$ ) ratio varies in a 
narrow range of 0.39-0.48. In the classification of Tischendorf et al. (1997), they plot dominantly in the Fe biotite field and some in the Mg biotite field (Fig. 9). However, they show some differences in the trace element compositions (Supplementary Table S3). The enclave biotite has lower Sr, Ba, $\mathrm{REE}, \mathrm{Y}, \mathrm{Zn}, \mathrm{Pb}, \mathrm{W}, \mathrm{Sc}, \mathrm{Co}, \mathrm{Ni}, \mathrm{Ga}$, and In contents, and higher Sn and V contents than that of the granodiorite (Fig. 10, Fig. 11).

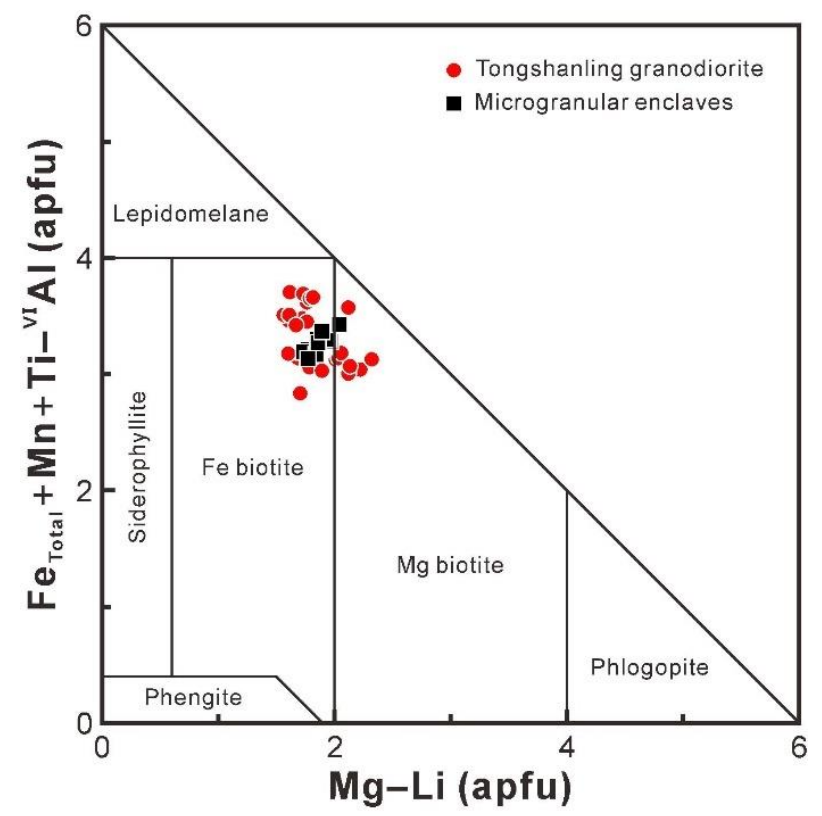

Fig. 9. Classification diagram of biotite (after Tischendorf et al., 1997) from the Tongshanling granodiorite and its microgranular enclaves.

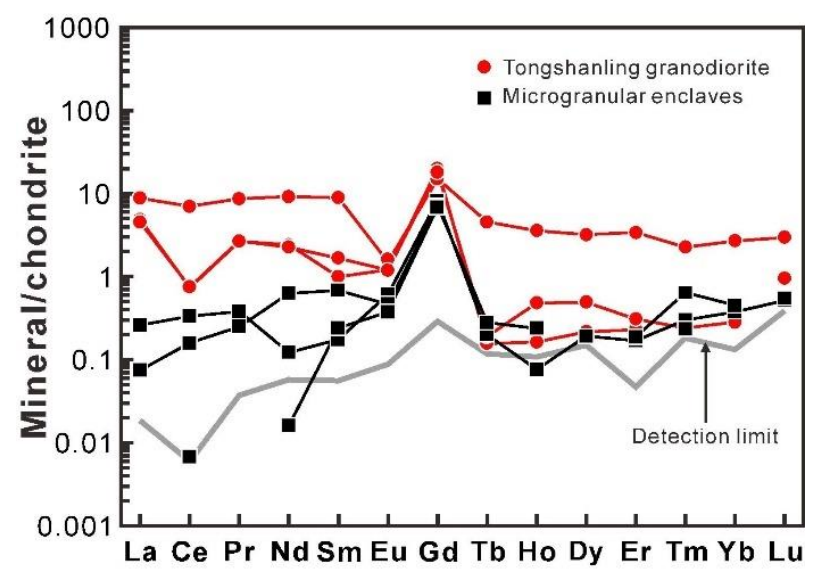

Fig. 10. Chondrite-normalized (Boynton, 1984) REE patterns of biotite from the Tongshanling granodiorite and its microgranular enclaves. 

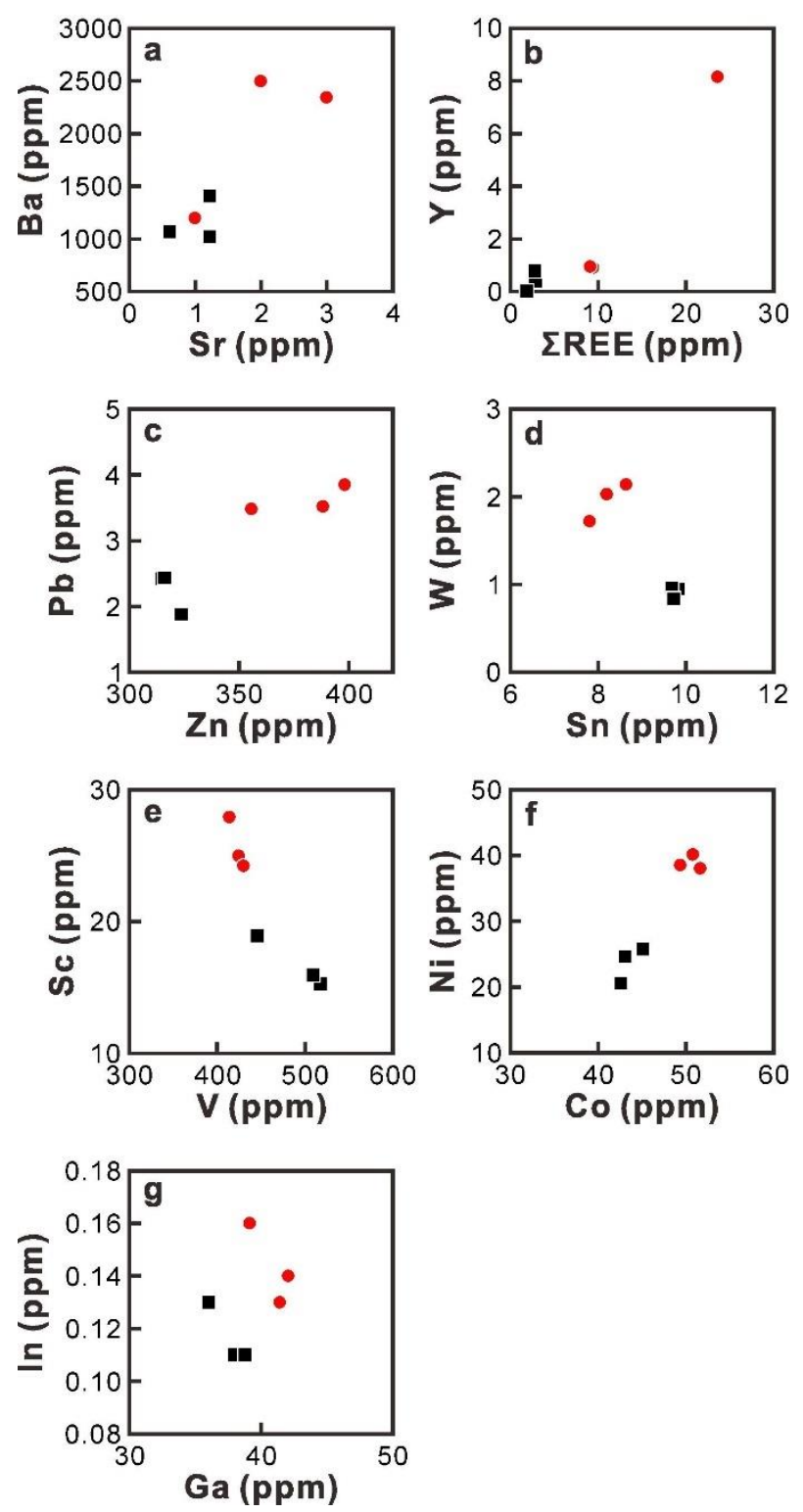

Fig. 11. Trace element binary diagrams of biotite from the Tongshanling granodiorite and its microgranular enclaves. Legends are the same as Fig. 9, Fig. 10.

\subsection{Zircon}

Magmatic zircon of the granodiorite shows well-developed oscillatory zoning, and generally includes an inherited core (Fig. 12a). Their $\mathrm{ThO}_{2}+\mathrm{UO}_{2}$ contents and $\mathrm{Zr} / \mathrm{Hf}$ ratios are 0.01$0.44 \mathrm{wt} \%$ and 68-94, respectively (Fig. 12b; Supplementary Table S5). In the enclaves, inherited zircon cores are also present (Fig. 12c). The magmatic zircon generally comprises an inner part with bright cathodoluminescence (CL) image and an outer part with dark CL image (Fig. 12c). The outer parts have higher $\mathrm{ThO}_{2}+\mathrm{UO}_{2}$ contents and lower $\mathrm{Zr} / \mathrm{Hf}$ ratios than the inner parts and are compositionally more similar to the magmatic zircon in the host granodiorite (Fig. 12b; Supplementary Table S5). It is worth noting that about $80 \%$ of the enclave zircon grains show chaotic internal textures without oscillatory zoning (Fig. 12d and e), and sometimes are surrounded by an oscillatory-zoned magmatic rim (Fig. 12f). 

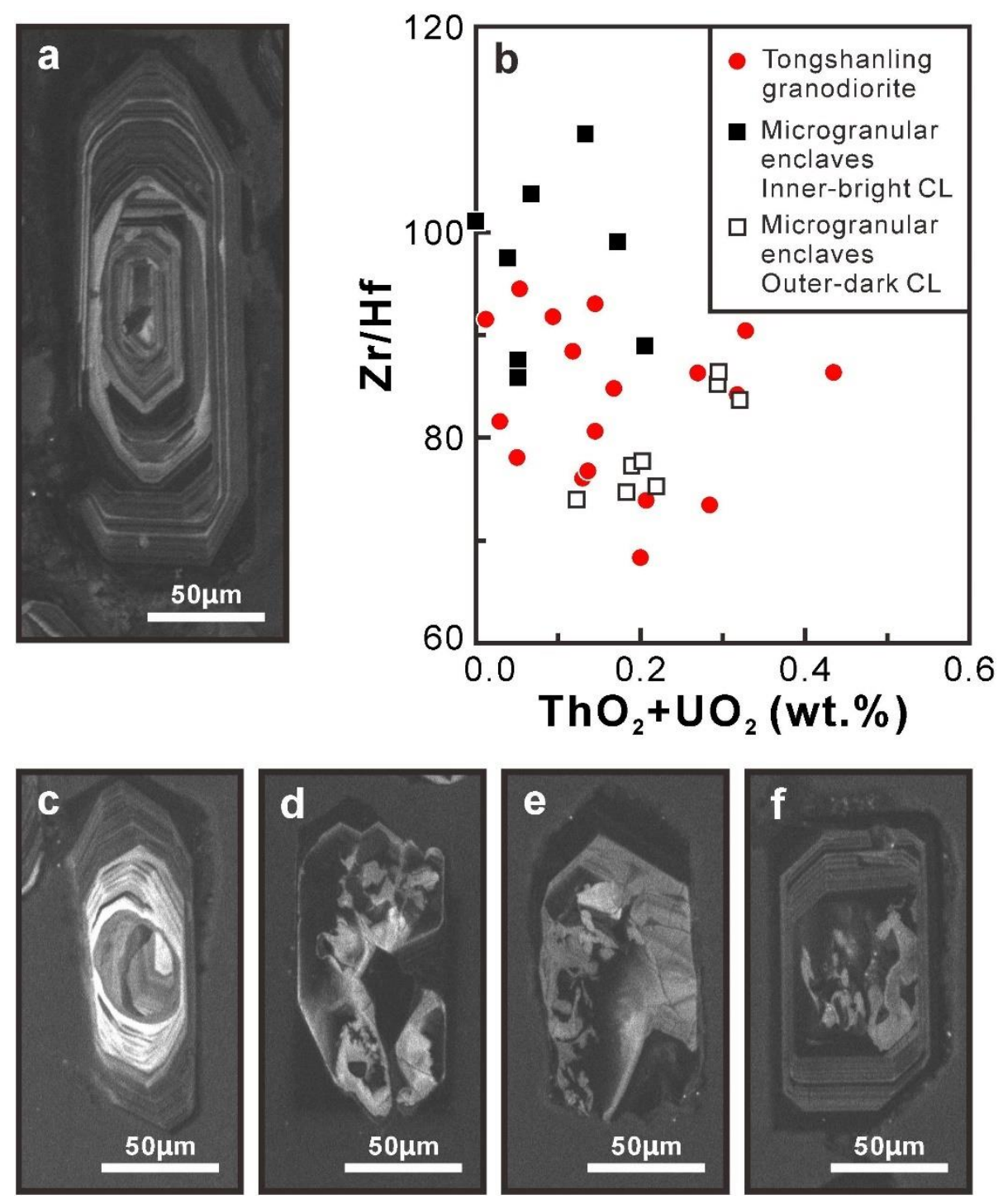

Fig. 12. Texture and mineral chemistry of zircon from the Tongshanling granodiorite and its microgranular enclaves. (a) CL image of a magmatic zircon with an inherited core from the granodiorite. (b) $\mathrm{Zr} / \mathrm{Hf}-\mathrm{ThO}_{2}+\mathrm{UO}_{2}$ (wt.\%) diagram of magmatic zircon from the granodiorite and its enclaves. (c) CL image showing the compositional zonation of a magmatic zircon with an inherited core from the enclaves. ( $d$ and e) Chaotic internal textures of metamorphic zircon in the enclaves. (f) Metamorphic zircon with a magmatic rim in the enclaves.

\section{Discussion}

\subsection{Textural evidence}

\subsubsection{Residual materials}

The restite model was mostly discussed and developed by the studies of granites and their enclaves in the Lachlan Fold Belt (White and Chappell, 1977, Chappell et al., 1987, Chen et al., 1989, Chen et al., 1990, Chen et al., 1991, Chappell and White, 1991, Chappell, 1996, White et al., 1999, Chappell and Wyborn, 2012). Restite microgranular enclaves in calcalkaline I-type granitoids generally have some diagnostic textural features as follows: (1) remnants of refractory materials, such as Ca-rich plagioclase, inherited zircon, and possibly 
pyroxene produced by dehydration melting reactions; (2) mafic mineral clots coexisted with Ca-rich plagioclase; (3) residual metamorphic texture inherited from the source.

In the enclaves of the Tongshanling granodiorite, mafic mineral clots are widely scattered (Fig. 3h, j, and m). These clots are comprised of anhedral to subhedral crystals and do not exhibit the typical texture of serial crystallization as in magmatic rocks. The metamorphogenic granoblastic triple-junction texture in the interior of zonal amphibole-rich clots (Fig. 31) directly reflects the restite information from the metamorphic source (Castro and Stephens, 1992, Sial et al., 1998). The commonly occurred old zircon cores (Fig. 12c; X.D. Huang et al., 2017) are also indicative of an inheritance from the crustal source. The chaotic internal texture of the dominant enclave zircon grains (Fig. 12d and e) is different from the magmatic oscillatory-zoned texture and is similar to the convoluted zoning and recrystallization texture of zircon formed by high-temperature metamorphism (Hoskin and Black, 2000, Corfu et al., 2003, Wu and Zheng, 2004, Harley et al., 2007). In all probability, this kind of zircon is metamorphic zircon maintained from the source after partial melting. With an irregular margin and almost uniform composition without zonation (Fig. 4b), the sericitized Ca-rich plagioclase cores are distinctly different from the fresh zonal magmatic plagioclase. The confined sericitization only in the core rather than in the rim (Fig. 4b) may indicate that the core plagioclase was an early existed phase which has been altered by magmatic fluids before the crystallization of rim plagioclase. Therefore, these plagioclase cores are thought to be of a restite origin. They are analogous to the residual plagioclase described by Chappell et al. (1987). The existence of these residual minerals implicates that the temperature of partial melting was insufficient to thoroughly melt the source materials. Thus, these microgranular enclaves are restite enclaves and show the same petrographic features as the restite enclaves of I-type granites in the Lachlan Fold Belt (e.g., Chen et al., 1990, Chen et al., 1991).

\subsubsection{Vestiges of magma reworking}

The textural vestiges of restite enclaves reworked by the host magma are evident in the microgranular enclaves. The plagioclase phenocrysts in the enclaves show identical features to the matrix plagioclase in the host granodiorite with a similar granularity and composition $\left(\mathrm{An}_{30}-\mathrm{An}_{40}\right.$, measured by optical microscope) and without Ca-rich cores (Fig. 3i). They were probably formed by transfer of accidental crystals from the host magma. White et al. (1999) emphasized that the restite enclaves could contain a melt phase which has been produced during partial melting but is insufficient to disaggregate the enclave into the magma. The reaction rim of plagioclase phenocryst (Fig. 3i) could be formed by reaction of the accidental plagioclase with the initial melt in the enclaves. Vernon (1991) pointed out that poikilitic texture results from magmatic crystallization with relatively low nucleation rates and high growth rates. Thus, the poikilitic texture of K-feldspar (Fig. 3n) and quartz (Fig. 3o) in the enclaves in all probability reflects an input of late-stage silica-rich melt from the host magma. There is a progressive change of texture and mineral proportion from the zonal amphibolerich clot interior to exterior (Fig. 3j-1) and then to the amphibole-biotite clot (Fig. 3m), with gradually obscurer granoblastic triple-junction texture and elevated biotite content, showing a progressive reaction process of the restite with the accidental melt from the host magma. This accidental melt was also probably responsible for the formation of the magmatic rims of residual plagioclase (Fig. 4b) and zircon (Fig. 12c and f). The process of magma reworking is also reflected by the gradational contact between the enclaves and the host granodiorite (Fig. $3 \mathrm{~g})$. 


\subsection{Compositional evidence}

\subsubsection{Magmatic amphibole}

Both natural amphibole (Duan and Jiang, 2017) and experimental studies (Schmidt, 1992, Ernst and Liu, 1998) have revealed that, during magmatic crystallization with decreasing pressure and temperature, the early-crystallized amphibole is more Al-enriched and $\mathrm{Si}$ depleted than the late-crystallized amphibole. The dominant idiomorphic isolated amphibole in the Tongshanling granodiorite shows normal magmatic growth zonation (Supplementary Table S2) and was evidently formed by magmatic crystallization. With higher Al and lower Si contents than the isolated amphibole (Fig. 6b), the enclosed amphibole is also of magmatic origin but was crystalized earlier than the isolated one. In the plot of the generalized tschermakite vs. edenite components (Fig. 13), the magmatic amphibole is distributed away from the tremolite end-member and is obviously separated from the other occurrences of amphibole. Assuming that the whole-rock composition of the Tongshanling granodiorite is similar to the melt composition from which the magmatic amphibole was crystallized, the REE distributions of model magmatic amphibole calculated by partition coefficients in felsic (dacitic to rhyolitic) melts (Arth, 1976) are consistent with those of the isolated amphibole (Fig. 14), further demonstrating its magmatic origin.

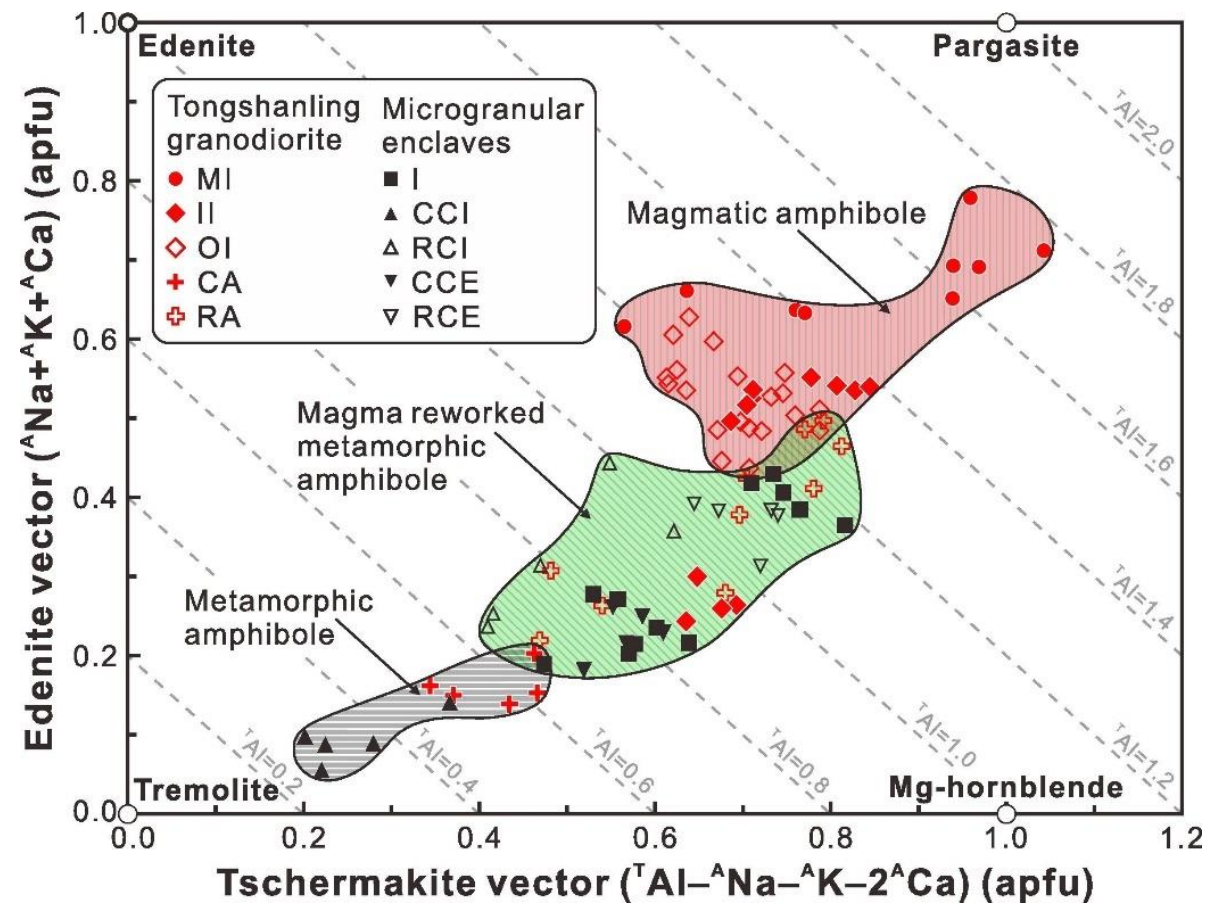

Fig. 13. Plot of the generalized tschermakite $\left[\left({ }^{\mathrm{T}} \mathrm{Al}-{ }^{\mathrm{A}} \mathrm{Na}-{ }^{\mathrm{A}} \mathrm{K}-2{ }^{\mathrm{A}} \mathrm{Ca}\right)(\mathrm{apfu})\right]$ vs. edenite $\left[\left({ }^{\mathrm{A}} \mathrm{Na}+{ }^{\mathrm{A}} \mathrm{K}+{ }^{\mathrm{A}} \mathrm{Ca}\right)(\right.$ apfu $\left.)\right]$ components for amphibole from the Tongshanling granodiorite and its microgranular enclaves (after Schumacher, 2007). Legends are the same as Fig. 6. 


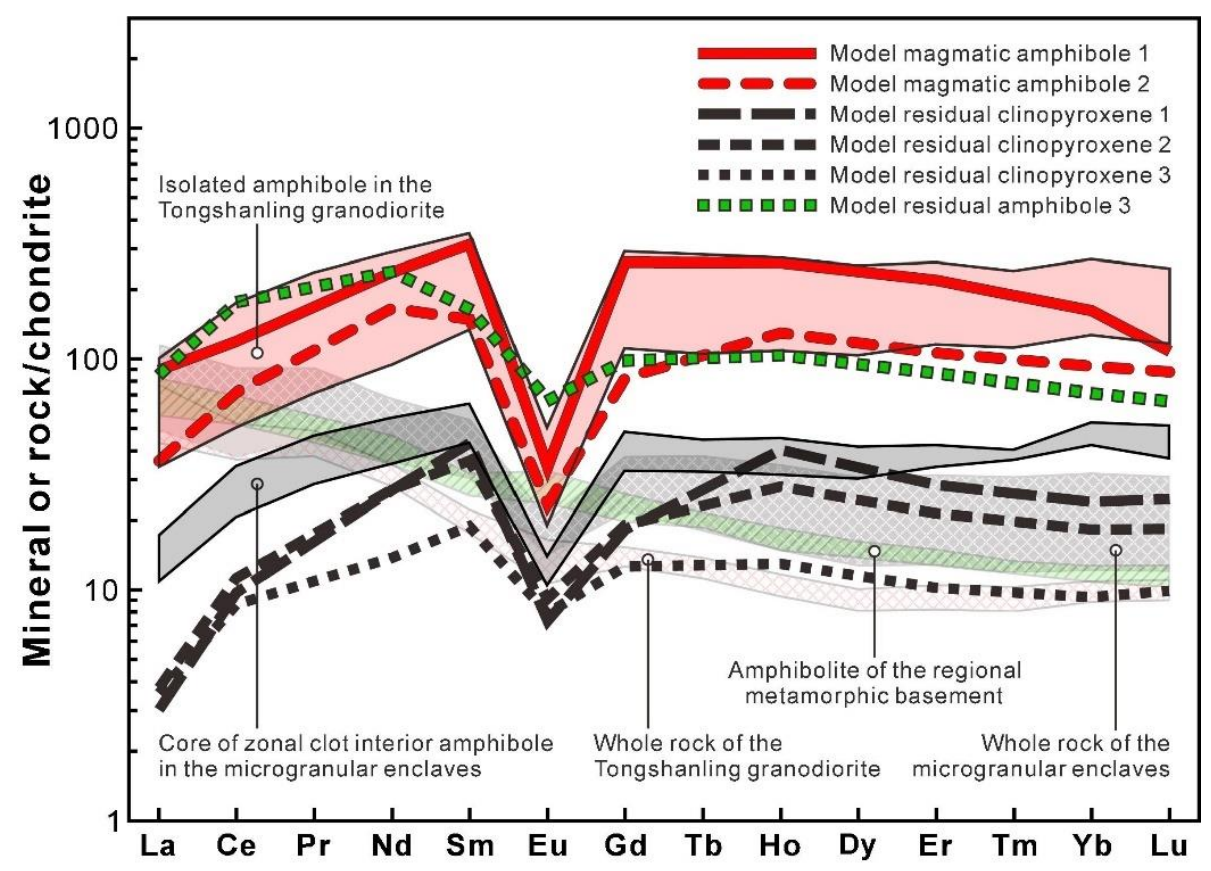

Fig. 14. REE distribution modelling of magmatic amphibole and residual clinopyroxene and amphibole. Model magmatic amphibole 1 and 2 are calculated by partition coefficients in felsic melts with rhyolitic and dacitic compositions (Arth, 1976), respectively, assuming that the whole-rock composition of the Tongshanling granodiorite is similar to the melt composition in which magmatic amphibole has been crystallized. Model residual clinopyroxene 1,2, and 3 are calculated by partition coefficients in dacitic melt (Arth, 1976, Fujimaki et al., 1984) in terms of $10 \%$ partial melting with a restite comprised of 30\% clinopyroxene $+70 \%$ plagioclase (model 1 ), $50 \%$ clinopyroxene $+50 \%$ plagioclase (model 2 ), and $45 \%$ clinopyroxene $+45 \%$ plagioclase $+10 \%$ amphibole (model 3 ), respectively, using the amphibolite of the regional metamorphic basement $(\mathrm{Li}, 1997)$ as the source rock. Model residual amphibole 3 is calculated by the restite model 3. The whole-rock REE compositions of the Tongshanling granodiorite and its microgranular enclaves are from X.D. Huang et al. (2017). The REE concentrations of all model residual minerals and natural samples are normalized by chondrite (Boynton, 1984).

\subsubsection{Metamorphic amphibole}

It is notable that, compared with the magmatic amphibole, the amphibole grains in the enclave zonal clots show a contrary compositional zonation and distinctly lower $\mathrm{Al}$ and higher $\mathrm{Si}$ contents (Fig. 6b; Supplementary Table S2), indicating that they were not formed by magmatic crystallization. The clot interior amphibole has a granoblastic triple-junction texture (Fig. 31) and the grain core is compositionally close to the tremolite end-member (Fig. 13), thus the actinolitic core amphibole is considered to be of a metamorphic origin. A study of analogous amphibole-rich clots in granodiorite by Castro and Stephens (1992) argued that the actinolitic core amphibole is actually a pseudomorph after a primary pyroxene-rich precursor, which is expected to be relatively poor in $\mathrm{Al}$ and has been transformed into amphibole by a complex reaction. They supposed that this reaction may have occurred by hydrogenation of the primary pyroxene with a magnesio-hornblende armor [pyroxene + fluids $(\mathrm{OH}$, etc.) $\rightarrow$ actinolite] or may also have occurred as a direct discontinuous reaction of the pyroxene with the melt (pyroxene + melt $_{1} \rightarrow$ hornblende + melt $_{2}$ ). Martin (2007) considered that the former hypothesis is more dependable. The actinolitic core amphibole in the Tongshanling microgranular enclaves contains significantly lower REE contents than the magmatic amphibole (Fig. 7a and b). It is consistent with the hypothesis that the actinolitic core amphibole was transformed from primary residual pyroxene which has significantly 
lower REE partition coefficients than amphibole in felsic melt (Arth, 1976, Fujimaki et al., 1984). This is also responsible for the distinctly lower contents of the other incompatible elements in the actinolitic core amphibole (Fig. 8a-h). It is reasonable that the incompatible elements tend to concentrate in melt during partial melting and give rise to a depleted remnant. The obvious Eu negative anomalies and weak LREE depletions of the actinolitic core amphibole (Fig. 7b) indicate the coexistence of plagioclase in residual materials (Stephens, 2001). This has been further demonstrated by the occurrence of abundant residual Ca-rich plagioclase cores in the enclaves. As revealed by previous experimental studies, dehydration melting of amphibolite at crustal pressure and temperature usually produces a pyroxene- and plagioclase-rich restite in which the pyroxene is dominated by clinopyroxene (Beard and Lofgren, 1991, Wolf and Wyllie, 1994, Johannes and Holtz, 1996). Using the amphibolite of the regional metamorphic basement $(\mathrm{Li}, 1997)$ as the source rock of the Tongshanling granodiorite, the REE distributions of model residual clinopyroxene calculated in terms of $10 \%$ partial melting with a model restite comprised of different proportions of clinopyroxene, plagioclase and amphibole are similar to the actinolitic core amphibole but with lower REE contents especially when residual amphibole occurs (Fig. 14). However, the model residual amphibole contains distinctly higher REE contents than the actinolitic core amphibole (Fig. 14). Thus, the results of REE distribution modeling indicate that the actinolitic core amphibole was transformed from primary residual pyroxene by hydrogenation, during which the REE contents had increased due to its higher REE partition coefficients, rather than directly preserved as residual amphibole.

\subsubsection{Magma reworked metamorphic amphibole}

The increasing $\mathrm{Al}$ and decreasing Si contents from core to rim of the clot interior amphibole grains and also from interior to exterior of the whole zonal clot (Fig. 6b), with a trend from metamorphic amphibole to magmatic amphibole (Fig. 13), show the process of magma reworking of the restite enclaves. In consideration of the consistent REE patterns with the magmatic amphibole (Fig. 7a and b), the rim of clot interior amphibole grains may have been formed by reaction of the actinolitic amphibole with the host magma. Castro and Stephens, 1992, Stephens, 2001 considered that this reaction was induced dominantly by diffusive exchange along the grain boundaries. With a similar compositional zonation to the clot interior amphibole but higher $\mathrm{Al}$ and lower Si contents (Fig. 6), the clot exterior amphibole was formed by a more intense magma reworking than the clot interior amphibole. The isolated enclave amphibole has magma reworked compositions (Fig. 13) and consistent REE patterns with the magmatic amphibole (Fig. 7a and c), suggesting that it is also magma reworked amphibole and is deduced to be transformed from isolated residual pyroxene. The high-Al and low-Si isolated amphibole may result from a more intense reworking by a late and evolved host melt than the low-Al and high-Si isolated amphibole.

\subsubsection{Zircon and plagioclase}

The composition zonation of enclave magmatic zircon (Fig. 12c) has recorded two different melts existed in the enclaves. X.D. Huang et al. (2017) reported that both the inner parts and outer parts of enclave magmatic zircon have consistent $\mathrm{U}-\mathrm{Pb}$ ages and $\mathrm{Hf}$ isotopic compositions with the magmatic zircon in the host granodiorite, indicating that they were sequentially crystallized from different melts with the same origin. The outer parts have higher $\mathrm{ThO}_{2}+\mathrm{UO}_{2}$ contents and lower $\mathrm{Zr} / \mathrm{Hf}$ ratios than the inner parts, and are more similar to those of the magmatic zircon in the host granodiorite (Fig. 12b), suggesting that the outer magmatic zircon was crystallized from a late and more evolved host melt, whereas, the inner 
parts with lower $\mathrm{ThO}_{2}+\mathrm{UO}_{2}$ contents and higher $\mathrm{Zr} / \mathrm{Hf}$ ratios (Fig. 12b) may be crystallized from the initial melt retained in restite. The magmatic rims of enclave plagioclase may have been crystallized from the initial melt or the evolved host melt. However, the consistent compositions of magmatic plagioclase in the enclaves and their host granodiorite (Fig. 5) and the discontinuous compositional change within the enclave plagioclase from core to rim (Fig. $4 \mathrm{~b})$ indicate that the magmatic rim plagioclase in the enclaves was in all probability dominantly crystallized from the evolved host melt.

\subsubsection{Biotite}

The temperature of biotite dehydration melting is much lower than that of amphibole dehydration melting (Johannes and Holtz, 1996). Therefore, the enclave biotite should not be a residual phase when amphibole broke down. However, it has lower contents of $\Sigma$ REE and some other incompatible elements such as $\mathrm{Sr}, \mathrm{Ba}, \mathrm{Y}, \mathrm{Zn}, \mathrm{Pb}$, and $\mathrm{W}$ than the magmatic biotite in the host granodiorite (Fig. 10, Fig. 11), reflecting some residual information. The consistent major element compositions of biotite in the granodiorite and its enclaves (Fig. 9) indicate an intense reworking of the restite by the host magma.

\subsubsection{Residual materials in the granodiorite}

There are also some residual materials in the host granodiorite, such as the old zircon cores (Fig. 12a), the Ca-rich plagioclase cores (Fig. 4a), and the rarely-occurred amphibole-rich clots (Fig. 3e). These residual materials can be directly inherited from the source after partial melting or can be derived from disaggregation of the restite enclaves reworked by the host magma. The amphibole-rich clots also have a metamorphic triple-junction texture (Fig. 3f) and mainly consist of granoblastic amphibole with an actinolitic core surrounded by a magnesio-hornblende rim (Fig. 6a), which are similar to those in the enclaves. In the amphibole-rich clots, the amphibole rim has distinctly higher $\mathrm{Al}$ and lower $\mathrm{Si}$ contents than the core (Fig. 6b), showing a magma reworked signature (Fig. 13). The low-Al and high-Si magma reworked isolated amphibole (Fig. 6, Fig. 13) may be derived from the disaggregation of amphibole-rich clots or transformed from isolated residual pyroxene just as in the enclaves.

\subsubsection{Geochemical signatures}

The Harker plots of the Tongshanling granodiorite and its microgranular enclaves show excellent linearities (Fig. 15). This phenomenon coincides with the restite model and was explained to be result from progressive separation of melt and restite (White and Chappell, 1977, Chappell et al., 1987). Previous studies showed that the microgranular enclaves have quite consistent evolved $\mathrm{Sr}-\mathrm{Nd}$ and zircon $\mathrm{Hf}$ isotopic compositions with their host granodiorite, with both the enclaves and granodiorite having respective $\left({ }^{87} \mathrm{Sr} /{ }^{86} \mathrm{Sr}\right)_{i}$ ratios of $0.710-0.711$ and $0.709-0.711, \varepsilon_{\mathrm{Nd}}(\mathrm{t})$ values of -6.7 to -5.0 and -6.9 to -4.2 , and zircon $\varepsilon_{\mathrm{Hf}}(\mathrm{t})$ values of -11.5 to -6.9 and -12.2 to -6.9 (Jiang et al., 2009, Zhao et al., 2016, X.D. Huang et al., 2017). They are distinct from those mantle-derived enclaves which have more juvenile isotopic signatures than the host granitoids (e.g., Yang et al., 2004, Yang et al., 2007, Zhao et al., 2010, Cheng et al., 2012, Fu et al., 2016). The almost contemporaneous mantle-derived mafic rocks adjacent to the Tongshanling intrusion show notably more juvenile isotopic compositions than the Tongshanling granodiorite and its enclaves, such as the Huziyan high$\mathrm{Mg}$ basalt [ca. $150 \mathrm{Ma},\left({ }^{87} \mathrm{Sr} /{ }^{86} \mathrm{Sr}\right)_{i}: 0.705-0.706, \varepsilon_{\mathrm{Nd}}(\mathrm{t}):-1.3$ to +0.7 ], Huilongxu lamprophyre [ca. $170 \mathrm{Ma},\left({ }^{87} \mathrm{Sr} /{ }^{86} \mathrm{Sr}\right)_{i}: 0.704-0.705, \varepsilon_{\mathrm{Nd}}(\mathrm{t}):-1.7$ to -1.3 ], and Ninyuan alkaline basalt [ca. $170 \mathrm{Ma},\left({ }^{87} \mathrm{Sr} /{ }^{86} \mathrm{Sr}\right){ }_{i}: 0.704-0.705, \varepsilon_{\mathrm{Nd}}(\mathrm{t}):+5.4$ to +6.1 ] (Wang et al., 
2003b, Li et al., 2004, Jiang et al., 2009). It was impossible to produce these enclaves with the same isotopic signatures as their host granodiorite by crust-mantle magma mixing. These isotopic features are suggestive of a crustal origin for the enclaves and preclude the possibility of mantle-derived mafic magmatic crystallization, which further support the interpretation of the enclaves as reworked restite.
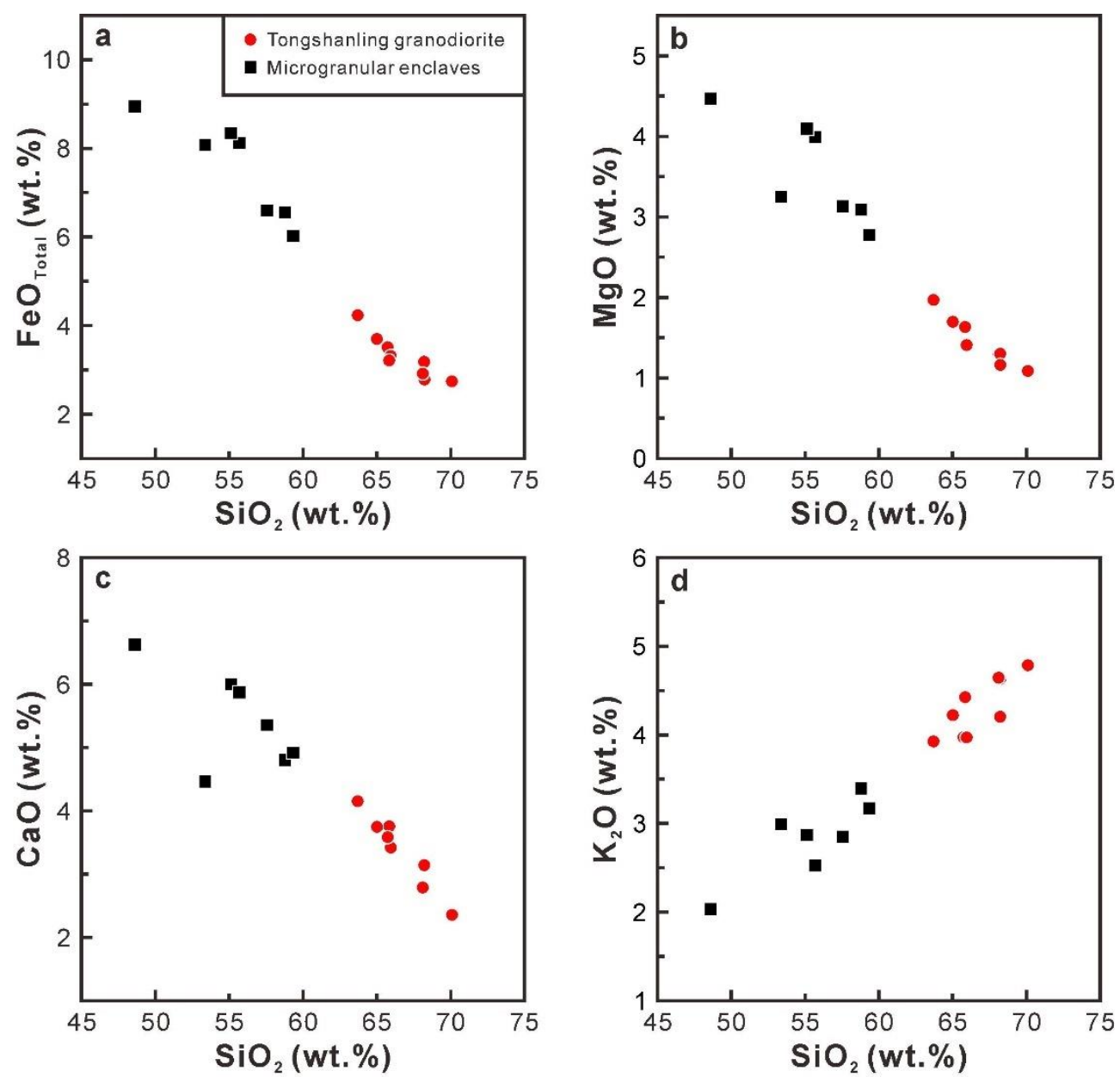

Fig. 15. Harker plots for (a) $\mathrm{FeO}_{\text {Total, }}$ (b) $\mathrm{MgO}$, (c) $\mathrm{CaO}$, and (d) $\mathrm{K}_{2} \mathrm{O}$ of the Tongshanling granodiorite and its microgranular enclaves showing excellent linearities. The data are from X.D. Huang et al. (2017).

\subsection{Geothermobarometry}

\subsubsection{Temperature}

Numerous mineral thermometers, include amphibole, plagioclase, and biotite, have been proposed to estimate the temperature conditions of magmatic process (e.g., Holland and Blundy, 1994, Henry et al., 2005, Putirka, 2005, Putirka, 2008, Putirka, 2016, Ridolfi and Renzulli, 2012). Various thermometers (Table 1) were applied for temperature calculation to test the interpretation for enclave origin. Most magma reworked amphibole crystals, except for the intensely reworked high-Al and low-Si isolated amphibole and the rim of clot exterior amphibole grains in the enclaves, were not used for calculation due to their distinct compositional disequilibrium (low $\mathrm{Al}$ and high Si contents) with the host melt which would 
inevitably lead to an underestimation of temperature. The detailed results are listed in Table 1. Although there are some differences between different calculation methods and some thermometers yielded overestimated (Ridolfi et al., 2010, Molina et al., 2015, Putirka, 2005; Eq. (4a) of Putirka, 2016) and underestimated (Eq. (4b) of Putirka, 2016) temperatures (Table $1)$, several general regularities are evident. The temperature recorded by magmatic amphibole decreases progressively from the enclosed ones through the inner and to the outer of isolated ones (Table 1; Fig. 16a and b). This is in accordance with their petrographic crystallization sequence. The actinolitic core amphibole and the $\mathrm{Ca}$-rich core plagioclase record distinctly higher temperatures than the isolated magmatic amphibole and the magmatic rim plagioclase, respectively (Table 1). This is consistent with the restite origin of the actinolitic core amphibole and the Ca-rich core plagioclase. The magmatic rim plagioclase and biotite in the enclaves show consistent temperatures with those in the host granodiorite, respectively (Table 1; Fig. 16c), suggesting that during the process of magma reworking the enclave plagioclase and biotite were in equilibrium with the host melt. The high- $\mathrm{Al}$ and low-Si isolated amphibole and the rim of clot exterior amphibole grains in the enclaves have similar temperatures which are slightly lower than that of the isolated magmatic amphibole (Table 1; Fig. 16a and b), indicating that the intensely reworked enclave amphibole was nearly in equilibrium with the host melt. However, they show notably lower temperatures than the early enclosed magmatic amphibole (Table 1; Fig. 16a and b), reflecting that an evolved host melt was responsible for the reworking of restite enclaves. The prediction of $\mathrm{SiO}_{2}$ in coexisting model melt with magmatic amphibole and intensely reworked enclave amphibole (Eqs. (10) and (5) of Putirka, 2016) yielded $\mathrm{SiO}_{2}$ contents of 65.3-70.1 wt \% and 68.4-69.7 wt \%, respectively, which match the whole-rock composition of the Tongshanling granodiorite $(63.7-70.1 \mathrm{wt} \%$, X.D. Huang et al., 2017) (Fig. 16b). It means that these amphibole crystals were basically in equilibrium with the host granodioritic magma and the temperature calculation is meaningful.

Table 1. Geothermometry based on mineral chemical compositions of amphibole, plagioclase, and biotite from the Tongshanling granodiorite and its microgranular enclaves.

\section{Geothermometer}

Amphibole

Amphibole

Amphibole $\mathrm{b}^{\mathrm{b}}$

Amphibole-liquid ${ }^{\mathrm{c}}$

Amphibole-liquid

Amphibole-liquid

Amphibole

\section{Temperature ${ }^{\mathrm{a}}\left({ }^{\circ} \mathrm{C}\right)$}

\section{Tongshanling granodiorite}

Microgranular enclaves

\section{Reference}

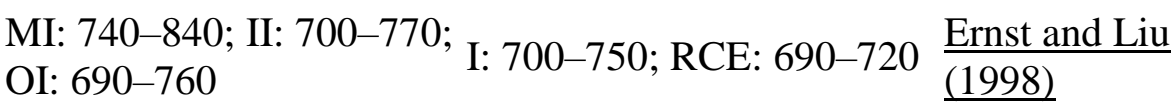

MI: 828-931; II: 818-844; I: 803-809; RCE: 783-795
OI: 801-842

Ridolfi et al.

$\underline{(2010)}$

Ridolfi and

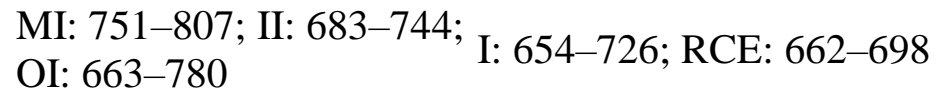

MI: 962-998; II: 976-984; I: 976-984; RCE: 969-974
OI: 971-989

Renzulli

(2012)

Molina et al. (2015)

MI: 897-919; II: 903-908; I: 879-886; RCE: 871-887
OI: 893-910

MI: 598-616; II: 596-603;

OI: 594-609

I: 595-603; RCE: 593-602

MI: 769-867; II: 771-792;

OI: $758-789$

I: 753-759; RCE: 739-751
Eq. (4a) of

Putirka (2016)

Eq. (4b) of

Putirka (2016)

Eq. (5) of

Putirka (2016) 


\begin{tabular}{|c|c|c|c|}
\hline Geothermometer & $\begin{array}{l}\text { Tongshanling } \\
\text { granodiorite }\end{array}$ & Microgranular enclaves & Reference \\
\hline Amphibole & $\begin{array}{l}\text { MI: 772-865; II: 769-787; } \\
\text { OI: 757-788 }\end{array}$ & I: 753-760; RCE: 740-752 & $\begin{array}{l}\text { Eq. (6) of } \\
\text { Putirka (2016) }\end{array}$ \\
\hline Amphibole & $\begin{array}{l}\text { MI: 764-858; II: 774-793; } \\
\text { OI: 763-784 }\end{array}$ & I: 755-763; RCE: 748-764 & $\begin{array}{l}\text { Eq. }(8) \text { of } \\
\text { Putirka }(2016) \\
\end{array}$ \\
\hline Amphibole-liquid & $\begin{array}{l}\text { MI: 786-877; II: 796-809; } \\
\text { OI: 788-803 }\end{array}$ & I: 784-788; RCE: 774-785 & $\begin{array}{l}\text { Eq. }(9) \text { of } \\
\text { Putirka }(2016) \\
\end{array}$ \\
\hline $\begin{array}{l}\text { Amphibole- } \\
\text { plagioclase }^{\mathrm{d}}\end{array}$ & $\begin{array}{l}\text { MI: 729-896; II: 710-782; } \\
\text { OI: 698-764 }\end{array}$ & I: 703-740; RCE: 682-728 & $\begin{array}{l}\text { Blundy and } \\
\text { Holland (1990) }\end{array}$ \\
\hline $\begin{array}{l}\text { Amphibole- } \\
\text { plagioclase (A) }\end{array}$ & $\begin{array}{l}\text { MI: 709-863; II: 700-801; } \\
\text { OI: 682-789 }\end{array}$ & I: 682-729; RCE: 679-737 & $\begin{array}{l}\text { Holland and } \\
\text { Blundy (1994) }\end{array}$ \\
\hline $\begin{array}{l}\text { Amphibole- } \\
\text { plagioclase (B) }\end{array}$ & $\begin{array}{l}\text { MI: 700-849; II: 676-775; } \\
\text { OI: 661-770; CA: 819- } \\
847\end{array}$ & $\begin{array}{l}\text { I: } 660-739 \text {; RCE: } 662-751 \\
\text { CCI: } 764-848\end{array}$ & $\underline{\text { Holland and }}$ \\
\hline Plagioclase-liquid & $\begin{array}{l}\text { Core: 1017-1030; } \\
\text { Intermediate: 990-999; } \\
\text { Rim: 956-972 }\end{array}$ & $\begin{array}{l}\text { Core: 1025-1031; } \\
\text { Intermediate: 994-995; } \\
\text { Rim: 960-973 }\end{array}$ & $\underline{\text { Putirka (2005) }}$ \\
\hline Biotite & $680-726$ & $694-733$ & $\frac{\text { Henry et al. }}{(2005)}$ \\
\hline
\end{tabular}

Notes

A : MI: mineral inclusion; II: inner of isolated amphibole; OI: outer of isolated amphibole; CA: core of aggregated amphibole grains; I: isolated amphibole; CCI: core of clot interior amphibole grains; RCE: rim of clot exterior amphibole grains. The low-Al and high-Si isolated amphibole was excluded for temperature calculation.

B : The pressure used for those pressure-dependent thermometers was $3 \mathrm{kbar}$ for the II, OI, I, and RCE amphibole, $5 \mathrm{kbar}$ for the MI amphibole, and $8 \mathrm{kbar}$ for the CA and CCI amphibole.

$\mathrm{C}$ : The model liquid used the averaged whole-rock composition of the Tongshanling granodiorite based on the data reported by X.D. Huang et al. (2017).

D : For the amphibole-plagioclase thermometers, the II, OI, I, and RCE amphibole, the MI amphibole, and the CA and CCI amphibole were supposed to be in equilibrium with the rim, intermediate, and core plagioclase, respectively. 

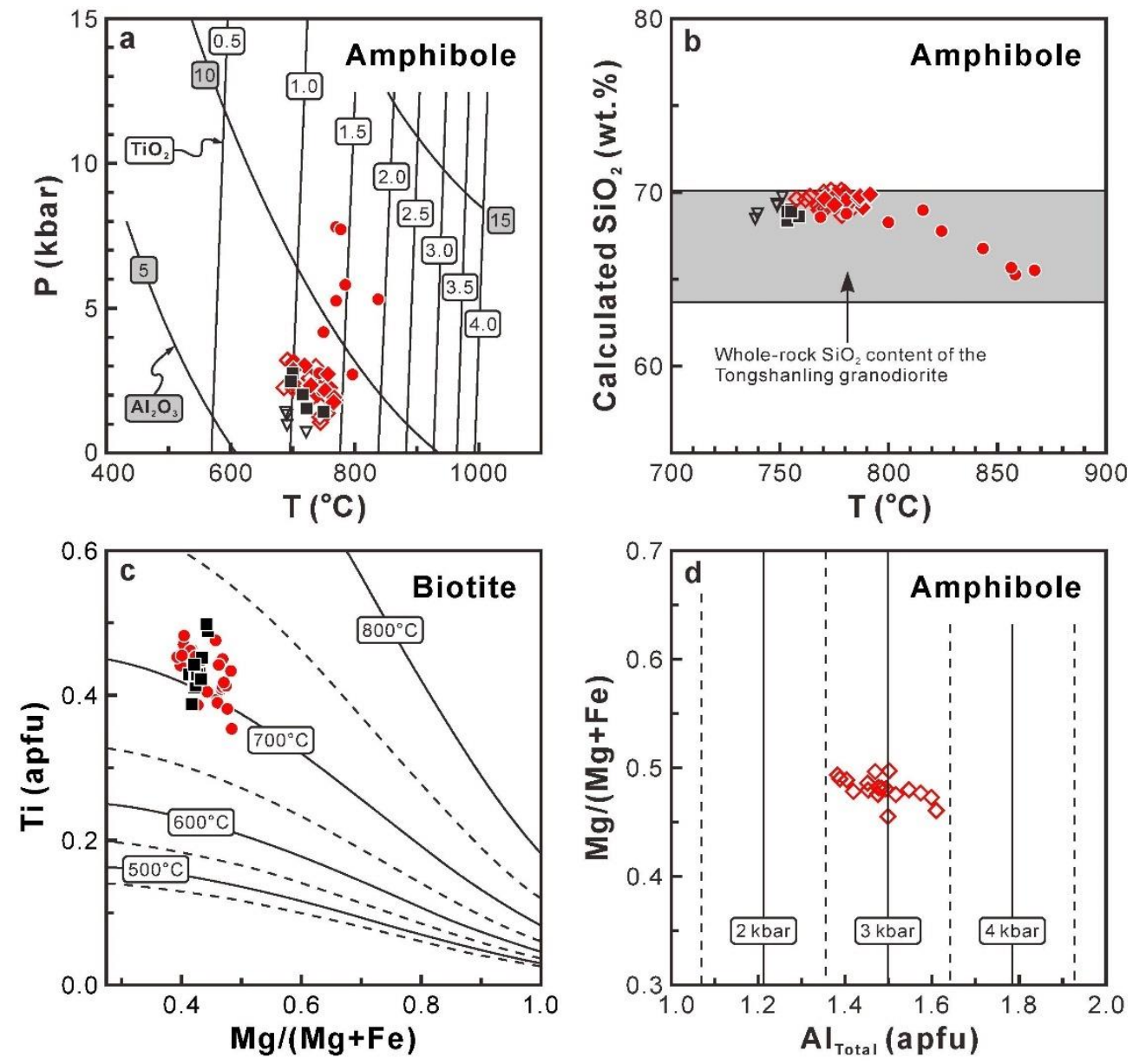

Fig. 16. Physicochemical conditions estimated by mineral chemical compositions of amphibole and biotite from the Tongshanling granodiorite and its microgranular enclaves. (a) Semiquantitative thermobarometer of amphibole based on $\mathrm{Al}_{2} \mathrm{O}_{3}$ and $\mathrm{TiO}_{2}$ contents (after Ernst and Liu, 1998). (b) Temperature and $\mathrm{SiO}_{2}$ content in coexisting model melt calculated by amphibole composition based on the Eqs. (5) and (10) of Putirka (2016). (c) Temperature calculated by the Ti-in-biotite geothermometer according to Henry et al. (2005), the dashed curves represent intermediate $50{ }^{\circ} \mathrm{C}$ interval isotherms. (d) Pressure calculated by the Al-in-hornblende geobarometer according to Anderson and Smith (1995), the dashed curves represent intermediate $0.5 \mathrm{kbar}$ interval isobars. Legends of amphibole and biotite are the same as Fig. 6 and Fig. 9, Fig. 10, respectively.

\subsubsection{Pressure}

Al-in-hornblende barometer can provide an effective approach to estimate the magma emplacement depth of near-solidus granitic systems with highly restrictive conditions (Schmidt, 1992, Anderson and Smith, 1995, Ridolfi and Renzulli, 2012, Mutch et al., 2016, Putirka, 2016). The Tongshanling granodiorite contains all the necessary equilibrium phases, i.e., hornblende + biotite + plagioclase + orthoclase + quartz + titanite $+\mathrm{Fe}-\mathrm{Ti}$ oxide + melt + fluid. Based on the calibration proposed by Anderson and Smith (1995), the rim compositions of magmatic isolated amphibole $[\mathrm{Mg} /(\mathrm{Mg}+\mathrm{Fe})>0.35]$ in the granodiorite give a pressure of 2.6-3.4 (3.0 \pm 0.4$) \mathrm{kbar}$ (calculated with $\left.\mathrm{T}=750^{\circ} \mathrm{C}\right)($ Fig. $16 \mathrm{~d})$, corresponding to a deep emplacement depth of $8.6-11.2 \mathrm{~km}(3.3 \mathrm{~km} / \mathrm{kbar})$ with an average value of ca. $10 \mathrm{~km}$. This result is consistent with those calculated by the calibration of Mutch et al. (2016) and the Eq. (7a) of Putirka (2016) on the whole, which are 2.7-3.6 kbar and 2.5$3.3 \mathrm{kbar}$, respectively. 
The Tongshanling granodiorite belongs to low-temperature granites in terms of the relatively low zircon saturation temperature (Table 2) and the occurrence of inherited zircon (Chappell et al., 2000, Miller et al., 2003). The low-temperature and deep-emplaced granodioritic magma is indicative of a relatively high viscosity to a certain extent which is favorable for carrying some residual materials from the source. Different from volcanic rocks in which the anhydrous primary residual minerals, such as pyroxene, can be commonly preserved as phenocrysts, the deep-emplaced magma is beneficial to drive an intense reworking of the residual materials during slow cooling (Chappell et al., 1987). Thus, the residual pyroxene might have been totally transformed into amphibole in such a deep-emplaced magma. This could account for the absence of residual pyroxene in the Tongshanling granodiorite and its microgranular enclaves.

Table 2. Main features of the major Middle-Late Jurassic $\mathrm{Cu}-\mathrm{Pb}-\mathrm{Zn}$-bearing granodiorites in the Nanling Range, South China.

\begin{tabular}{|c|c|c|c|c|}
\hline Intrusion & Shuikoushan & Baoshan & Tongshanling & Dabaosha \\
\hline Metal association & $\mathrm{Pb}-\mathrm{Zn}-\mathrm{Au}-\mathrm{Ag}$ & $\begin{array}{l}(\mathrm{Cu}, \mathrm{Mo})-\mathrm{Pb}- \\
\mathrm{Zn}-\mathrm{Ag}\end{array}$ & $\mathrm{Cu}(\mathrm{Mo})-\mathrm{Pb}-\mathrm{Zn}-\mathrm{Ag}$ & $\begin{array}{l}\mathrm{Mo}(\mathrm{W})-\mathrm{Cu}-\mathrm{Pb} \\
\mathrm{Fe}\end{array}$ \\
\hline Lithology & \multicolumn{4}{|c|}{$\begin{array}{l}\text { Porphyritic to equigranular biotite granodiorite with a dominant mineralog } \\
\text { plagioclase }+ \text { K-feldspar }+ \text { quartz }+ \text { biotite } \pm \text { amphibole }\end{array}$} \\
\hline Accessory minerals & \multicolumn{4}{|c|}{$\begin{array}{l}\text { Apatite, zircon, titanite, allanite, rutile, sulfide minerals, and Fe-Ti oxide } \\
\text { minerals (mainly magnetite) }\end{array}$} \\
\hline Dark enclaves & $\begin{array}{l}\text { Have not been } \\
\text { reported }\end{array}$ & Observed & Observed & $\begin{array}{l}\text { Have not been } \\
\text { reported }\end{array}$ \\
\hline $\begin{array}{l}\text { Zircon U-Pb age } \\
\text { (Ma) }\end{array}$ & $\begin{array}{l}156.0 \pm 1.0 \\
158.8 \pm 1.8 \\
158.3 \pm 1.2\end{array}$ & $\begin{array}{l}158.0 \pm 2.0 \\
156.7 \pm 1.4 \\
157.7 \pm 1.1\end{array}$ & $\begin{array}{l}163.6 \pm 2.1 \\
160.7 \pm 0.5, \\
160.5 \pm 0.9, \\
159.7 \pm 0.8, \\
162.5 \pm 1.0\end{array}$ & $\begin{array}{l}167.0 \pm 2.5, \\
162.2 \pm 0.7 \\
161.0 \pm 0.9, \\
160.2 \pm 0.9, \\
166.3 \pm 2.0 \\
166.2 \pm 2.7 \\
162.1 \pm 1.6\end{array}$ \\
\hline $\begin{array}{l}\text { Metallogenic age } \\
\text { (Ma) (Molybdenite } \\
\text { Re-Os dating) }\end{array}$ & $157.8 \pm 1.4$ & $160 \pm 2$ & $\begin{array}{l}161.8 \pm 1.7 \\
160.1 \pm 0.8,161 \pm 1 \\
162.2 \pm 1.6\end{array}$ & $\begin{array}{l}163.9 \pm 1.3 \\
164.8 \pm 0.8\end{array}$ \\
\hline Evolutionary degree & Low & Low & Low & Low \\
\hline $\mathrm{SiO}_{2}($ wt. $\%)$ & $59.6-65.2$ & $62.6-68.8$ & $63.7-70.1$ & $64.4-72.9$ \\
\hline $\mathrm{ASI}^{\mathrm{a}}$ & $0.9-1.1$ & $0.8-1.0$ & $0.9-1.0$ & $1.0-1.1$ \\
\hline $\mathrm{CaO} /\left(\mathrm{Na}_{2} \mathrm{O}+\mathrm{K}_{2} \mathrm{O}\right)$ & $0.3-0.8$ & $0.3-0.9$ & $0.3-0.7$ & $0.2-0.8$ \\
\hline $\mathrm{Mg} /(\mathrm{Mg}+\mathrm{Fe})$ & $0.4-0.6$ & $0.4-0.6$ & $0.4-0.5$ & $0.3-0.7$ \\
\hline $\mathrm{Rb} / \mathrm{Sr}$ & $0.2-0.4$ & $0.5-2.9$ & $0.4-1.3$ & $1.2-2.1$ \\
\hline
\end{tabular}




\section{Intrusion}

Shuikoushan

Baoshan

Tongshanling

Dabaoshan

\begin{tabular}{|c|c|c|c|c|}
\hline$\delta \mathrm{Eu}^{\underline{\mathrm{b}}}$ & $0.8-1.0$ & $0.6-0.8$ & $0.6-1.0$ & $0.6-0.8$ \\
\hline LREE/HREE & $8.7-16.1$ & $7.0-10.6$ & $5.1-11.3$ & $10.3-18.0$ \\
\hline$\Sigma$ REE (ppm) & $120-234$ & $124-271$ & $82-189$ & $134-236$ \\
\hline $\mathrm{HFSE}^{\mathrm{c}}(\mathrm{ppm})$ & $229-267$ & $198-282$ & $165-264$ & $175-284$ \\
\hline $\mathrm{T}_{\mathrm{Zr}}{ }^{\mathrm{d}}\left({ }^{\circ} \mathrm{C}\right)$ & $726-775$ & $722-760$ & $738-772$ & $739-774$ \\
\hline$\left({ }^{87} \mathrm{Sr} /{ }^{86} \mathrm{Sr}\right)_{i}$ & $0.710-0.711$ & $0.710-0.712$ & $0.709-0.711$ & $0.704-0.714$ \\
\hline$\varepsilon_{\mathrm{Nd}}(t)$ value & -6.6 to -5.9 & -7.3 to -5.0 & -6.9 to -4.2 & -8.2 to -6.8 \\
\hline Zircon $\varepsilon_{\mathrm{Hf}}(t)$ value & -10.8 to -7.9 & -12.0 to -9.2 & -12.2 to -6.9 & -11.8 to -7.5 \\
\hline References & $\begin{array}{l}\text { Huang et al., } \\
\text { 2015, Wang et al., } \\
\text { 2003a, Yang et al., } \\
\text { 2016, Zuo et al., } \\
2014\end{array}$ & $\begin{array}{l}\text { Lu et al., } \\
\text { 2006, Wang et } \\
\text { al., 2003a, Xie } \\
\text { et al., 2013 }\end{array}$ & $\begin{array}{l}\text { Huang and Lu, 2014, } \\
\text { Jiang et al., 2009, Lu } \\
\text { et al., 2015, Wang et } \\
\text { al., 2003a, X.D. Huang } \\
\text { et al., 2017, Zhao et } \\
\text { al., } 2016\end{array}$ & $\begin{array}{l}\text { Li et al., 2012, Mao } \\
\text { et al., 2013, Qu et } \\
\text { al., 2014, W.T. } \\
\text { Huang et al., 2017, } \\
\text { Wang, 2010, Wang } \\
\text { et al., 2011 }\end{array}$ \\
\hline
\end{tabular}

Notes
A : Aluminum saturation index, $\mathrm{ASI}=n\left(\mathrm{Al}_{2} \mathrm{O}_{3}\right) / n\left(\mathrm{CaO}+\mathrm{Na}_{2} \mathrm{O}+\mathrm{K}_{2} \mathrm{O}\right)$.
$\mathrm{B}: \delta \mathrm{Eu}=2 \mathrm{Eu}_{N} /\left(\mathrm{Sm}_{\mathrm{N}}+\mathrm{Gd}_{N}\right)$.
$\mathrm{C}:$ High field strength elements, $\mathrm{HFSE}=\mathrm{Zr}+\mathrm{Nb}+\mathrm{Ce}+\mathrm{Y}$.
D : Zircon saturation temperature, $T_{z r}$ was calculated by the method of Miller et al. (2003).

\subsection{The model for reworked restite enclave}

Based on the nature of reworked restite enclaves with distinct textural and compositional features described above, the formation process of the microgranular enclaves in the Tongshanling granodiorite is deduced as follows (Fig. 17). 

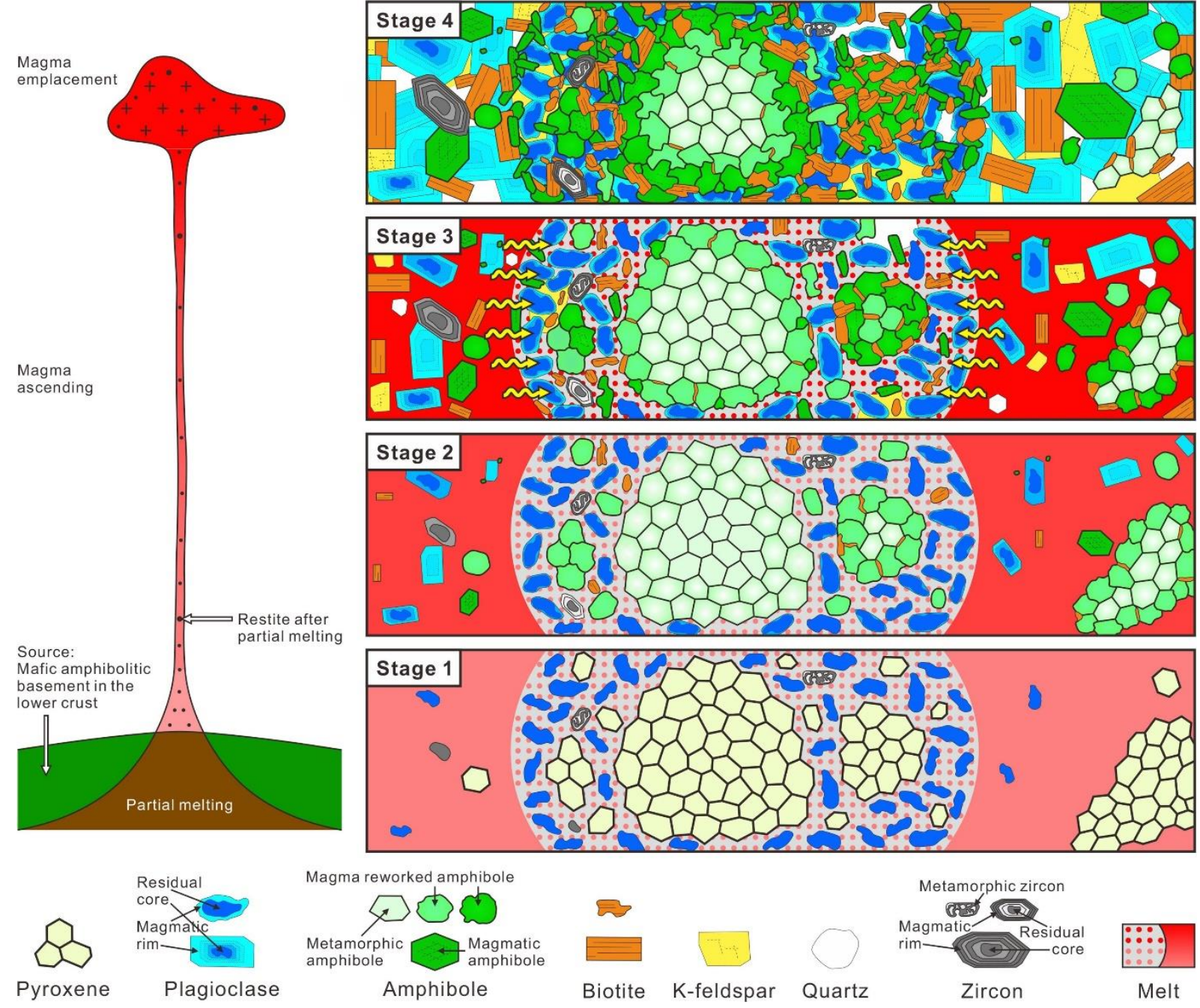

Fig. 17. Schematic model illustrating the formation process of reworked restite enclave (see detailed description in the text). In the right diagram, the center and the surrounding parts show the evolutionary processes of the restite enclave and the host granodioritic magma, respectively. To better explain this model, the melt content in the enclave (spots in the center part of the right diagram) and the zircon size have been magnified. For the magma reworked amphibole, the deeper colored ones have a more intense reaction with the melt and higher $\mathrm{Al}$ contents than the paler colored ones.

Stage 1: Formation of granodioritic melt and restite during partial melting. Partial melting of the mafic amphibolitic basement in the lower crust produced a metaluminous and high-K calc-alkaline granodioritic melt coexisted with a primary pyroxene-rich restite that mainly comprised of pyroxene, plagioclase, and also refractory accessory minerals, such as zircon. Most melt was extracted and constituted a granodioritic magma with a few residual materials. There were still a few initial melts maintained in the restite due to its high viscosity.

Stage 2: Preliminary reaction of the restite enclave with the initial melt. Some fragments of restite were carried by the ascending host magma. With the cooling of magma, the inner parts of magmatic zircon were firstly crystallized from the initial melt in the restite enclaves. The pyroxene-rich precursors were transformed into actinolite by progressive hydrogenation from exterior to interior. Some small clots had a more intense reaction with the initial melt and 
formed magnesio-hornblende and a few biotite in the exteriors. The isolated residual pyroxene was also transformed into magnesio-hornblende with low $\mathrm{Al}$ and high Si contents.

Stage 3: Further reaction of the restite enclave with the evolved host melt. The composition of the host melt was gradually evolved with crystallization. Progressive input of the evolved host melt led to a further reaction of the restite enclaves with the melt. This resulted in the formation of the outer parts of magmatic zircon and the magmatic rims around residual Carich plagioclase. The exteriors of most clots had been transformed into magnesio-hornblende. The small clots showed more Al-enriched and Si-depleted compositions of magnesiohornblende and might have a higher biotite content than the large ones due to the more intense reaction with the melt. Some low-Al and high-Si isolated amphibole crystals were transformed into high-Al and low-Si ones.

Stage 4: Formation of the reworked restite enclave. With the reaction between the restite enclaves and the host magma, the zonal amphibole-rich clots had been formed. The small clots might have been transformed into non-zoning amphibole-rich clots or amphibole-biotite clots. The input of late-stage silica-rich melt from the host magma led to the formation of the poikilitic texture of K-feldspar and quartz in the restite enclaves. After the granodioritic magma had been completely solidified, the reworked restite enclaves were survived as dark microgranular enclaves in the host granodiorite.

\section{Petrogenetic implications}

Restite may provide an important indication for the source nature of the host granitoids since it is remnant of refractory material after partial melting of the source rocks. Because the Tongshanling microgranular enclaves are restite which has been partially modified by the host granodioritic magma, the primary restite should be more mafic than the dioritic compositions. The pyroxene-rich precursors of the amphibole-rich clots, which have silica-poor compositions and mainly consist of pyroxene and Ca-rich plagioclase, may represent the primary restite from the source after partial melting. To produce such a composition of primary restite and a granodioritic magma showing I-type features, the source should have a relatively mafic composition, such as amphibolite (e.g., Chen et al., 1990, Sial et al., 1998, Stephens, 2001).

Dehydration melting of amphibolite can generate metaluminous granodioritic melts with a pyroxene-rich restite at pressure lower than $10 \mathrm{kbar}$ (Beard and Lofgren, 1991, Johannes and Holtz, 1996), whereas, water-saturated melting of amphibolite will produce strongly peraluminous melts with a restite dominated by amphibole (Beard and Lofgren, 1991). A pressure estimation of granulitic mafic xenoliths (8.8-12.4 kbar; Dai et al., 2008) in the Huziyan basalt (ca. $150 \mathrm{Ma}$ ), which occurs at $20 \mathrm{~km}$ north-northeast to the Tongshanling intrusion, suggests that the mafic amphibolitic basement should be located at a depth corresponding to a pressure lower than $8.8 \mathrm{kbar}$. Therefore, dehydration melting of amphibolite at pressure lower than $8.8 \mathrm{kbar}$ was in all probability responsible for the origin of the metaluminous Tongshanling granodiorite. The zircon Hf model ages of the Tongshanling granodiorite and its microgranular enclaves (1.5-2.1 Ga and 1.6-2.0 Ga, respectively, both with a peak value of $1.75 \mathrm{Ga}$; Jiang et al., 2009, Zhao et al., 2016, X.D. Huang et al., 2017) indicate that the amphibolitic basement was mainly formed in Paleoproterozoic. The occurrence of the Tianjinping amphibolite (1766 $\pm 19 \mathrm{Ma}$; Li, 1997) from the basement of the Cathaysia Block confirms the existence of the Paleoproterozoic amphibolitic basement in the Nanling Range. 
It is noteworthy that, the lower crust of South China, especially the mafic amphibolitic basement, has fertile ore-forming metals. For instance, the amphibolites of the Tianjinping Formation and the Mayuan Group have $\mathrm{Cu}$ contents of $57.7 \mathrm{ppm}$ and $66.5 \mathrm{ppm}$, and $\mathrm{Zn}$ contents of $119 \mathrm{ppm}$ and $118 \mathrm{ppm}$, respectively (Li, 1997), which are distinctly higher than those of the middle and upper crusts in South China (Gao et al., 1998) and are also higher than those of the lower crust reported by Rudnick and Fountain (1995). Such a fertile source is beneficial to the formation of $\mathrm{Cu}-\mathrm{Pb}-\mathrm{Zn}$-bearing granodiorites in the Nanling Range.

The Middle-Late Jurassic $\mathrm{Cu}-\mathrm{Pb}-\mathrm{Zn}$-bearing granodiorites in the Nanling Range have similar mineralogical and geochemical features (Table 2). They are generally hornblende-bearing, metaluminous and high-K calc-alkaline rocks with high $\mathrm{Mg} /(\mathrm{Mg}+\mathrm{Fe})$ ratios and low evolutionary degrees, and show characteristics of I-type granites (Table 2). They also have similar evolved Sr-Nd and zircon Hf isotopic compositions (Table 2). With regard to the previously proposed two different genetic models for these $\mathrm{Cu}-\mathrm{Pb}-\mathrm{Zn}$-bearing granodiorites, i.e., crust-mantle mixing and partial melting of the mafic lower crust, our research stands by the latter and provides inspiration for the further study.

\section{Acknowledgements}

We sincerely thank Ida Di Carlo at ISTO, Jian-Feng Gao and Liang Li at Nanjing FocuMS Technology Co. Ltd. for their technical assistance with EMP and LA-ICP-MS analyses, respectively. Rong-Qing Zhang is thanked for providing the critical references. We are grateful to Editor-in-Chief Prof. Mei-Fu Zhou, two anonymous reviewers, and Dr. Wen Winston Zhao for their efficient handling and valuable comments. This work was supported by the China Geological Survey Program (grant number 12120113067300), the French Labex Voltaire Project (grant number ANR-10-LABX-100-01), and the Sino-French Cai Yuanpei Program of China Scholarship Council.

\section{References}

Anderson and Smith, 1995

J.L. Anderson, D.R. SmithT he effects of temperature and $f_{\mathrm{O} 2}$ on the Al-in-hornblende barometer

Am. Mineral., 80 (1995), pp. 549-559

Arth, 1976

J.G. ArthB ehaviour of trace elements during magmatic processes-a summary of theoretical models and their applications

J. Res. U.S Geol. Surv., 4 (1976), pp. 41-47

Beard and Lofgren, 1991

J.S. Beard, G.E. Lofgren Dehydration melting and water-saturated melting of basaltic and andesitic greenstones and amphibolites at 1, 3, and $6.9 \mathrm{~kb}$

J. Petrol., 32 (1991), pp. 365-401

Blundy and Holland, 1990

J.D. Blundy, T.J.B. Holland Calcic amphibole equilibria and a new amphiboleplagioclase geothermometer

Contrib. Miner. Petrol., 104 (1990), pp. 208-224 
Blundy and Sparks, 1992

J.D. Blundy, R.S.J. Sparks Petrogenesis of mafic inclusions in granitoids of the Adamello Massif, Italy

J. Petrol., 33 (1992), pp. 1039-1104

Boynton, 1984

W.V. Boynton Cosmochemistry of the rare earth elements: meteorite studies

P. Henderson (Ed.), Rare Earth Element Geochemistry, Elsevier, Amsterdam (1984), pp. 63-114

Castro and Stephens, 1992

A. Castro, W.E. Stephens Amphibole-rich polycrystalline clots in calc-alkaline granitic rocks and their enclaves

Can. Mineral., 30 (1992), pp. 1093-1112

Chappell, 1996

B.W. Chappell Magma mixing and the production of compositional variation within granite suites: evidence from the granites of southeastern Australia

J. Petrol., 37 (1996), pp. 449-470

Chappell et al., 1987

B.W. Chappell, A.J.R. White, D. Wyborn The importance of residual source material (restite) in granite petrogenesis

J. Petrol., 28 (1987), pp. 1111-1138

Chappell and Wyborn, 2012

B.W. Chappell, D. Wyborn Origin of enclaves in S-type granites of the Lachlan Fold Belt

Lithos, 154 (2012), pp. 235-247

Chappell and White, 1991

B.W. Chappell, A.J.R. White Restite enclaves and the restite model

J. Didier, B. Barbarin (Eds.), Enclaves and Granite Petrology, Elsevier, Amsterdam (1991), pp. 375-381

Chappell et al., 2000

B.W. Chappell, A.J.R. White, I.S. Williams, D. Wyborn, L.A.I. Wyborn Lachlan

Fold Belt granites revisited: high- and low-temperature granites and their implications

Aust. J. Earth Sci., 47 (2000), pp. 123-138

Chen et al., 2008

J. Chen, J.J. Lu, W.F. Chen, R.C. Wang, D.S. Ma, J.C. Zhu, W.L. Zhang, J.F. Ji WSn-Nb-Ta-bearing granites in the Nanling Range and their relationship to metallogengesis

Geol. J. China Univ., 14 (2008), pp. 459-473

(in Chinese with English abstract)

Chen et al., 1989 
Y.D. Chen, R.C. Price, A.J.R. White Inclusions in three S-type granites from southeastern Australia

J. Petrol., 30 (1989), pp. 1181-1218

Chen et al., 1990

Y.D. Chen, R.C. Price, A.J.R. White, B.W. Chappell Mafic inclusions from the Glenbog and Blue Gum granite suites, southeastern Australia

J. Geophys. Res., 95 (1990), pp. 17757-17785

Chen et al., 1991

Y.D. Chen, B.W. Chappell, A.J.R. White Mafic enclaves of some I-type granites of the Palaeozoic Lachlan Fold Belt, southeastern Australia

J. Didier, B. Barbarin (Eds.), Enclaves and Granite Petrology, Elsevier, Amsterdam (1991), pp. 113-124

Chen et al., 2013

J. Chen, R.C. Wang, J.C. Zhu, J.J. Lu, D.S. Ma Multiple-aged granitoids and related tungsten-tin mineralization in the Nanling Range, South China

Sci. China Earth Sci., 56 (2013), pp. 2045-2055

Cheng et al., 2012

Y.B. Cheng, C. Spandler, J.W. Mao, B.G. Rusk Granite, gabbro and mafic microgranular enclaves in the Gejiu area, Yunnan Province, China: a case of two-stage mixing of crust- and mantle-derived magmas

Contrib. Miner. Petrol., 164 (2012), pp. 659-676

Corfu et al., 2003

F. Corfu, J.M. Hanchar, P.W.O. Hoskin, P. Kinny Atlas of zircon textures

Rev. Mineral. Geochem., 53 (2003), pp. 469-500

Dai et al., 2008

B.Z. Dai, S.Y. Jiang, Y.H. Jiang, K.D. Zhao, D.Y. Liu Geochronology, geochemistry and Hf-Sr-Nd isotopic compositions of Huziyan mafic xenoliths, southern Hunan Province, South China: Petrogenesis and implications for lower crust evolution Lithos, 102 (2008), pp. 65-87

Didier, 1973

J. Didier Granites and Their Enclaves

Elsevier, Amsterdam (1973)

Didier and Barbarin, 1991

J. Didier, B. Barbarin Enclaves and Granite Petrology

Elsevier, Amsterdam (1991)

Dorais et al., 1990

M.J. Dorais, J.A. Whitney, M.F. Roden Origin of mafic enclaves in the Dinkey

Creek pluton, Central Sierra Nevada Batholith, California

J. Petrol., 31 (1990), pp. 853-881

$\underline{\text { Duan and Jiang, } 2017}$ 
D.F. Duan, S.Y. Jiang In situ major and trace element analysis of amphiboles in quartz monzodiorite porphyry from the Tonglvshan $\mathrm{Cu}-\mathrm{Fe}$ (Au) deposit, Hubei Province, China: insights into magma evolution and related mineralization Contrib. Miner. Petrol., 172 (2017), p. 36

\section{Ernst and Liu, 1998}

W.G. Ernst, J. Liu Experimental phase-equilibrium study of Al- and Ti-contents of calcic amphibole in MORB-a semiquantitative thermobarometer

Am. Mineral., 83 (1998), pp. 952-969

$\underline{F u}$ et al., 2016

L.B. Fu, J.H. Wei, J. Tan, M. Santosh, D.H. Zhang, J.J. Chen, Y.J. Li, S.Q. Zhao, L.N. Peng Magma mixing in the Kalaqin core complex, northern North China Craton: Linking deep lithospheric destruction and shallow extension

Lithos, 260 (2016), pp. 390-412

\section{Fujimaki et al., 1984}

H. Fujimaki, M. Tatsumoto, K.-I. Aoki Partition coefficients of Hf, Zr, and REE between phenocrysts and groundmasses

J. Geophys. Res., 89 (suppl) (1984), pp. B662-B672

Gao et al., 1998

S. Gao, T.C. Luo, B.R. Zhang, H.F. Zhang, Y.W. Han, Z.D. Zhao, Y.K. Hu Chemical composition of the continental crust as revealed by studies in East China Geochim. Cosmochim. Acta, 62 (1998), pp. 1959-1975

Harley et al., 2007

S.L. Harley, N.M. Kelly, A. Möller Zircon behaviour and the thermal histories of mountain chains

Elements, 3 (2007), pp. 25-30

Hawthorne et al., 2012

F.C. Hawthorne, R. Oberti, G.E. Harlow, W.V. Maresch, R.F. Martin, J.C.

Schumacher, M.D. Welch IMA report: Nomenclature of the amphibole supergroup

Am. Mineral., 97 (2012), pp. 2031-2048

Henry et al., 2005

D.J. Henry, C.V. Guidotti, J.A. Thomson The Ti-saturation surface for low-tomedium pressure metapelitic biotites: implications for geothermometry and Tisubstitution mechanisms

Am. Mineral., 90 (2005), pp. 316-328

Holland and Blundy, 1994

T. Holland, J. Blundy Non-ideal interactions in calcic amphiboles and their bearing on amphibole-plagioclase thermometry

Contrib. Miner. Petrol., 116 (1994), pp. 433-447

$\underline{\text { Hoskin and Black, } 2000}$ 
P.W.O. Hoskin, L.P. Black Metamorphic zircon formation by solid-state recrystallization of protolith igneous zircon

J. Metamorph. Geol., 18 (2000), pp. 423-439

Hu et al., 2017

R.Z. Hu, W.T. Chen, D.R. Xu, M.F. Zhou Reviews and new metallogenic models of mineral deposits in South China: an introduction

J. Asian Earth Sci., 137 (2017), pp. 1-8

W.T. Huang et al., 2017

W.T. Huang, H.Y. Liang, J. Wu, Y.Q. Zou, J. Zhang Formation of porphyry Mo deposit in a deep fault zone, example from the Dabaoshan porphyry Mo deposit in northern Guangdong, South China

Ore Geol. Rev., 81 (2017), pp. 940-952

Huang and Lu, 2014

X.D. Huang, J.J. Lu Geological characteristics and Re-Os geochronology of Tongshanling polymetallic ore field, South Hunan, China

Acta Geol. Sin. (English Edition), 88 (suppl. 2) (2014), pp. 1626-1629

X.D. Huang et al., 2017

X.D. Huang, J.J. Lu, S. Sizaret, R.C. Wang, D.S. Ma, R.Q. Zhang, X. Zhao, J.W. Wu Petrogenetic differences between the Middle-Late Jurassic Cu-Pb-Zn-bearing and W-bearing granites in the Nanling Range, South China: a case study of the Tongshanling and Weijia deposits in southern Hunan Province

Sci. China Earth Sci., 60 (2017), pp. 1220-1236

Huang et al., 2015

J.C. Huang, J.T. Peng, J.H. Yang, B.L. Zhang, C.X. Xu Precise zircon U-Pb and molybdenite Re-Os dating of the Shuikoushan granodiorite-related $\mathrm{Pb}-\mathrm{Zn}$ mineralization, southern Hunan, South China

Ore Geol. Rev., 71 (2015), pp. 305-317

Jiang et al., 2009

Y.H. Jiang, S.Y. Jiang, B.Z. Dai, S.Y. Liao, K.D. Zhao, H.F. Ling Middle to late Jurassic felsic and mafic magmatism in southern Hunan province, southeast China: Implications for a continental arc to rifting

Lithos, 107 (2009), pp. 185-204

Johannes and Holtz, 1996

W. Johannes, F. Holtz Petrogenesis and Experimental Petrology of Granitic Rocks Springer, Berlin (1996)

Laumonier et al., 2014b

M. Laumonier, B. Scaillet, M. Pichavant, R. Champallier, J. Andujar, L. Arbaret On the conditions of magma mixing and its bearing on andesite production in the crust

Nat. Commun., 5 (2014), p. 5607

$\underline{\text { Laumonier et al., 2014a }}$ 
M. Laumonier, B. Scaillet, L. Arbaret, R. Champallier Experimental simulation of magma mixing at high pressure

Lithos, 196-197 (2014), pp. 281-300

\section{Laumonier et al., 2015}

M. Laumonier, B. Scaillet, L. Arbaret, J. Andújar, R. Champallier Experimental mixing of hydrous magmas

Chem. Geol., 418 (2015), pp. 158-170

Leake et al., 1997

B.E. Leake, A.R. Woolley, C.E.S. Arps, W.D. Birch, M.C. Gilbert, J.D. Grice, F.C. Hawthorne, A. Kato, H.J. Kisch, V.G. Krivovichev, K. Linthout, J. Laird, J.A. Mandarino, W.V. Maresch, E.H. Nickel, N.M.S. Rock, J.C. Schumacher, D.C. Smith, N.C.N. Stephenson, L. Ungaretti, E.J.W. Whittaker, Y.Z. Guo Nomenclature of amphiboles: Report of the subcommittee on amphiboles of the International Mineralogical Association, Commission on New Minerals and Mineral Names Can. Miner., 35 (1997), pp. 219-246

\section{$\underline{\mathrm{Li}, 1997}$}

X.H. Li Timing of the Cathaysia Block formation: Constraints from SHRIMP UPb zircon geochronology

Episodes, 20 (1997), pp. 188-192

\section{Li et al., 2004}

Li, X.H., Chung, S.L., Zhou, H.W., Lo, C.H., Liu, Y., Chen, C.H., 2004. Jurassic intraplate magmatism in southern Hunan-eastern Guangxi: 40Ar/39Ar dating, geochemistry, Sr-Nd isotopes and implications for tectonic evolution of SE China. In: Malpas, J., Fletcher, C.J.N., Ali, J.R., Aitchison, J.C. (Eds.), Aspects of the tectonic evolution of China. Geological Society, London, Special Publications, vol. 226, pp. 193-216.

$\underline{\text { Li et al., } 2012}$

C.Y. Li, H. Zhang, F.Y. Wang, J.Q. Liu, Y.L. Sun, X.L. Hao, Y.L. Li, W.D. Sun The formation of the Dabaoshan porphyry molybdenum deposit induced by slab rollback

Lithos, 150 (2012), pp. 101-110

$\underline{\mathrm{Li} \text { and } \mathrm{Li}, 2007}$

Z.X. Li, X.H. Li Formation of the 1300-km-wide intracontinental orogen and postorogenic magmatic province in Mesozoic South China: a flat-slab subduction model

Geology, 35 (2007), pp. 179-182

Liu et al., 2008

Y.S. Liu, Z.C. Hu, S. Gao, D. Günther, J. Xu, C.G. Gao, H.H. Chen In situ analysis of major and trace elements of anhydrous minerals by LA-ICP-MS without applying an internal standard

Chem. Geol., 257 (2008), pp. 34-43

$\underline{\text { Liu et al., } 2013}$ 
L. Liu, J.S. Qiu, Z. Li Origin of mafic microgranular enclaves (MMEs) and their host quartz monzonites from the Muchen pluton in Zhejiang Province, Southeast China: implications for magma mixing and crust-mantle interaction

Lithos, 160-161 (2013), pp. 145-163

\section{$\underline{\text { Lu et al., } 2015}$}

Y.Y. Lu, J.M. Fu, S.B. Cheng, S.S. Liu, C.B. Li, L.G. Zhang, L.Y. Ma Rock-forming and ore-forming ages of Tongshanling copper polymetallic ore-field in southern Hunan Province

Geotecton. Metallogen., 39 (2015), pp. 1061-1071

(in Chinese with English abstract)

\section{Lu et al., 2006}

Y.F. Lu, L.Y. Ma, W.J. Qu, Y.P. Mei, X.Q. Chen U-Pb and Re-Os isotope geochronology of Baoshan Cu-Mo polymetallic deposit in Hunan province Acta Petrol. Sin., 22 (2006), pp. 2483-2492

(in Chinese with English abstract)

Luo et al., 2015

B.J. Luo, H.F. Zhang, W.C. Xu, L. Guo, F.B. Pan, H. Yang The Middle Triassic

Meiwu batholith, West Qinling, Central China: implications for the evolution of compositional diversity in a composite batholith

J. Petrol., 56 (2015), pp. 1139-1172

Mao et al., 2013

W. Mao, X.F. Li, F.C. Yang Zircon LA-ICP-MS U-Pb ages of granites at Dabaoshan polymetallic deposit and its geological significance, Guangdong, South China

Acta Petrol. Sin., 29 (2013), pp. 4104-4120

(in Chinese with English abstract)

Martin, 2007

R.F. Martin Amphiboles in the igneous environment

Rev. Mineral. Geochem., 67 (2007), pp. 323-358

$\underline{\text { Miller et al., } 2003}$

C.F. Miller, S. Meschter McDowell, R.W. Mapes Hot and cold granites?

Implications of zircon saturation temperatures and preservation of inheritance Geology, 31 (2003), pp. 529-532

Molina et al., 2015

J.F. Molina, J.A. Moreno, A. Castro, C. Rodríguez, G.B. Fershtater Calcic amphibole thermobarometry in metamorphic and igneous rocks: new calibrations based on plagioclase/amphibole Al-Si partitioning and amphibole/liquid Mg partitioning Lithos, 232 (2015), pp. 286-305

Mutch et al., 2016

E.J.F. Mutch, J.D. Blundy, B.C. Tattitch, F.J. Cooper, R.A. Brooker An experimental study of amphibole stability in low-pressure granitic magmas and a revised Al-inhornblende geobarometer 
Contrib. Miner. Petrol., 171 (2016), p. 85

Perugini and Poli, 2012

D. Perugini, G. Poli The mixing of magmas in plutonic and volcanic environments: analogies and differences

Lithos, 153 (2012), pp. 261-277

Poli and Tommasini, 1991

G.E. Poli, S. Tommasini Model for the origin and significance of microgranular enclaves in calc-alkaline granitoids

J. Petrol., 32 (1991), pp. 657-666

$\frac{\text { Putirka, } 2005}{\text { KD }}$

K.D. Putirka Igneous thermometers and barometers based on plagioclase + liquid equilibria: tests of some existing models and new calibrations

Am. Mineral., 90 (2005), pp. 336-346

Putirka, 2008

K.D. Putirka Thermometers and barometers for volcanic systems

Rev. Mineral. Geochem., 69 (2008), pp. 61-120

$\underline{\text { Putirka, } 2016}$

K. PutirkaAmphibole thermometers and barometers for igneous systems and some implications for eruption mechanisms of felsic magmas at arc volcanoes Am. Mineral., 101 (2016), pp. 841-858

Qu et al., 2014

H.Y. Qu, M.H. Chen, F.C. Yang, Z.H. Gao, Y.W. Wang, H.J. Zhao, Z.F. Yu Metallogenic chronology of the stratiform $\mathrm{Cu}$ orebody in the Dabaoshan $\mathrm{Cu}$ polymetallic deposit, northern Guangdong Province and its geological significance

Acta Petrol. Sin., 30 (2014), pp. 152-162

(in Chinese with English abstract)

Regional Geological Survey Team of Hunan Geology Bureau, 1975a

Regional Geological Survey Team of Hunan Geology Bureau, 1975a. Geology Map of the People's Republic of China: Daoxian (G-49-XXII, scale 1:200000) (in Chinese).

Regional Geological Survey Team of Hunan Geology Bureau, 1975b

Regional Geological Survey Team of Hunan Geology Bureau, 1975b. Geology Map of the People's Republic of China: Jiangyong (G-49-XXVIII, scale 1:200000) (in Chinese).

$\underline{\text { Ridolfi et al., } 2010}$

F. Ridolfi, A. Renzulli, M. Puerini Stability and chemical equilibrium of amphibole in calc-alkaline magmas: an overview, new thermobarometric formulations and application to subduction-related volcanoes

Contrib. Miner. Petrol., 160 (2010), pp. 45-66

$\underline{\text { Ridolfi and Renzulli, } 2012}$ 
F. Ridolfi, A. Renzulli Calcic amphiboles in calc-alkaline and alkaline magmas:

thermobarometric and chemometric empirical equations valid up to $1,130{ }^{\circ} \mathrm{C}$ and 2.2 GPa

Contrib. Miner. Petrol., 163 (2012), pp. 877-895

$\underline{\text { Rudnick and Fountain, } 1995}$

R.L. Rudnick, D.M. Fountain Nature and composition of the continental crust: a lower crustal perspective

Rev. Geophys., 33 (1995), pp. 267-309

$\underline{\text { Sato and Sato, } 2009}$

E. Sato, H. Sato Study of effect of magma pocket on mixing of two magmas with different viscosities and densities by analogue experiments

J. Volcanol. Geoth. Res., 181 (2009), pp. 115-123

Schmidt, 1992

M.W. Schmidt Amphibole composition in tonalite as a function of pressure: an experimental calibration of the Al-in-hornblende barometer

Contrib. Miner. Petrol., 110 (1992), pp. 304-310

Schumacher, 2007

J.C. Schumacher Metamorphic amphiboles: composition and coexistence

Rev. Mineral. Geochem., 67 (2007), pp. 359-416

$\underline{\text { Sial et al., } 1998}$

A.N. Sial, V.P. Ferreira, A.E. Fallick, M.J.M. Cruz Amphibole-rich clots in calcalkalic granitoids in the Borborema province, northeastern Brazil

J. S. Am. Earth Sci., 11 (1998), pp. 457-471

Stephens, 2001

W.E. Stephens Polycrystalline amphibole aggregates (clots) in granites as potential I-type restite: an ion microprobe study of rare-earth distributions Aust. J. Earth Sci., 48 (2001), pp. 591-601

$\underline{\text { Sun, } 2006}$

T. Sun A new map showing the distribution of granites in South China and its explanatory notes

Geol.1 Bull. China, 25 (2006), pp. 332-335

(in Chinese with English abstract)

Tischendorf et al., 1997

G. Tischendorf, B. Gottesmann, H.-J. Förster, R.B. Trumbull On Li-bearing micas: estimating $\mathrm{Li}$ from electron microprobe analyses and an improved diagram for graphical representation

Miner. Mag., 61 (1997), pp. 809-834

Vernon, 1984

R.H. Vernon Microgranitoid enclaves in granites-globules of hybrid magma quenched in a plutonic environment

Nature, 309 (1984), pp. 438-439 
Vernon, 1991

R.H. Vernon Interpretation of microstructures of microgranitoid enclaves

J. Didier, B. Barbarin (Eds.), Enclaves and Granite Petrology, Elsevier, Amsterdam (1991), pp. 277-291

Wang et al., 2003a

Y.J. Wang, W.M. Fan, F. Guo G eochemistry of early Mesozoic potassium-rich diorites-granodiorites in southeastern Hunan Province, South China: petrogenesis and tectonic implications

Geochem. J., 37 (2003), pp. 427-448

Wang et al., 2003b

Y.J. Wang, W.M. Fan, F. Guo, T.P. Peng, C.W. Li Geochemistry of Mesozoic mafic rocks adjacent to the Chenzhou-Linwu fault, South China: implications for the lithospheric boundary between the Yangtze and Cathaysia blocks

Int. Geol. Rev., 45 (2003), pp. 263-286

Wang et al., 2011

L. Wang, M.A. Hu, Z. Yang, W.J. Qu, J.L. Xia, K.X. Chen U-Pb and Re-Os geochronology and geodynamic setting of the Dabaoshan polymetallic deposit, northern Guangdong Province, South China

Ore Geol. Rev., 43 (2011), pp. 40-49

Wang, 2010

L. Wang Metallogenic Model and Prospecting Potential in Dabaoshan

Molybdenum Polymetallic Ore Deposit, North Guangdong Province

(Ph.D. thesis)

China University of Geosciences, Wuhan (2010), pp. 1-119

(in Chinese with English abstract)

White and Chappell, 1977

A.J.R. White, B.W. Chappell Ultrametamorphism and granitoid genesis

Tectonophysics, 43 (1977), pp. 7-22

White et al., 1999

A.J.R. White, B.W. Chappell, D. Wyborn Application of the restite model to the Deddick granodiorite and its enclaves-a reinterpretation of the observations and data of Maas et al. (1997)

J. Petrol., 40 (1999), pp. 413-421

Wolf and Wyllie, 1994

M.B. Wolf, P.J. Wyllie Dehydration-melting of amphibolite at 10 kbar: the effects of temperature and time

Contrib. Miner. Petrol., 115 (1994), pp. 369-383

Wu et al., 2007

F.Y. Wu, X.H. Li, J.H. Yang, Y.F. Zheng Discussions on the petrogenesis of granites

Acta Petrol. Sin., 23 (2007), pp. 1217-1238

(in Chinese with English abstract) 
$\underline{\text { Wu and Zheng, } 2004}$

Y.B. Wu, Y.F. Zheng Genesis of zircon and its constraints on interpretation of $U$ Pb age

Chin. Sci. Bull., 49 (2004), pp. 1554-1569

$\underline{\text { Xie et al., } 2013}$

Y.C. Xie, J.J. Lu, D.S. Ma, R.Q. Zhang, J.F. Gao, Y. Yao Origin of granodiorite porphyry and mafic microgranular enclave in the Baoshan $\mathrm{Pb}-\mathrm{Zn}$ polymetallic deposit, southern Hunan Province: Zircon U-Pb chronological, geochemical and Sr-Nd-Hf isotopic constraints

Acta Petrol. Sin., 29 (2013), pp. 4186-4214

(in Chinese with English abstract)

Yang et al., 2004

J.H. Yang, F.Y. Wu, S.L. Chung, S.A. Wilde, M.F. Chu Multiple sources for the origin of granites: Geochemical and $\mathrm{Nd} / \mathrm{Sr}$ isotopic evidence from the Gudaoling granite and its mafic enclaves, northeast China

Geochim. Cosmochim. Acta, 68 (2004), pp. 4469-4483

Yang et al., 2007

J.H. Yang, F.Y. Wu, S.A. Wilde, L.W. Xie, Y.H. Yang, X.M. Liu Tracing magma mixing in granite genesis: in situ $\mathrm{U}$-Pb dating and $\mathrm{Hf}$-isotope analysis of zircons Contrib. Miner. Petrol., 153 (2007), pp. 177-190

Yang et al., 2016

J.H. Yang, J.T. Peng, Y.F. Zheng, R.Z. Hu, X.W. Bi, J.H. Zhao, J.C. Huang, B.L. Zhang Petrogenesis of the Mesozoic Shuikoushan peraluminous I-type granodioritic intrusion in Hunan Province, South China: Middle-lower crustal reworking in an extensional tectonic setting

J. Asian Earth Sci., 123 (2016), pp. 224-242

$\underline{\text { Zhang et al., } 2016}$

J.J. Zhang, T. Wang, A. Castro, L. Zhang, X.J. Shi, Y. Tong, Z.C. Zhang, L. Guo, Q.D. Yang, L.M. Iaccheri Multiple mixing and hybridization from magma source to final emplacement in the Permian Yamatu pluton, the Northern Alxa Block, China

J. Petrol., 57 (2016), pp. 933-980

Zhao et al., 2010

K.D. Zhao, S.Y. Jiang, J.C. Zhu, L. Li, B.Z. Dai, Y.H. Jiang, H.F. Ling Hf isotopic composition of zircons from the Huashan-Guposhan intrusive complex and their mafic enclaves in northeastern Guangxi: Implication for petrogenesis Chin. Sci. Bull., 55 (2010), pp. 509-519

$\underline{\text { Zhao et al., } 2016}$

P.L. Zhao, S.D. Yuan, J.W. Mao, M. Santosh, C. Li, K.J. Hou Geochronological and petrogeochemical constraints on the skarn deposits in Tongshanling ore district, southern Hunan Province: Implications for Jurassic $\mathrm{Cu}$ and $\mathrm{W}$ metallogenic events in South China 
Ore Geol. Rev., 78 (2016), pp. 120-137

Zhao et al., 2017

W.W. Zhao, M.F. Zhou, Y.H.M. Li, Z. Zhao, J.F. Gao Genetic types, mineralization styles, and geodynamic settings of Mesozoic tungsten deposits in South China J. Asian Earth Sci., 137 (2017), pp. 109-140

Zhao and Zhou, 2018

W.W. Zhao, M.F. Zhou Mineralogical and metasomatic evolution of the Jurassic Baoshan scheelite skarn deposit, Nanling, South China

Ore Geol. Rev., 95 (2018), pp. 182-194

Zhou et al., 2013

Q. Zhou, Y.H. Jiang, H.H. Zhang, S.Y. Liao, G.D. Jin, P. Zhao, R.Y. Jia, Z. Liu Mantle origin of the Dexing porphyry copper deposit, SE China

Int. Geol. Rev., 55 (2013), pp. 337-349

Zhou and Li, 2000

X.M. Zhou, W.X. Li Origin of Late Mesozoic igneous rocks in Southeastern China: implications for lithosphere subduction and underplating of mafic magmas

Tectonophysics, 326 (2000), pp. 269-287

Zuo et al., 2014

C.H. Zuo, R. Lu, Z.X. Zhao, Z.W. Xu, J.J. Lu, R.C. Wang, J.Q. Chen

Characterization of element geochemistry, LA-ICP-MS zircon U-Pb age, and $\mathrm{Hf}$ isotope of granodiorite in the Shuikoushan deposit, Changning, Hunan Province Geol. Rev., 60 (2014), pp. 811-823

(in Chinese with English abstract) 